\title{
Review \\ CK1 Is a Druggable Regulator of Microtubule Dynamics and Microtubule-Associated Processes
}

\author{
Aileen Roth ${ }^{1}$, Adrian Gihring ${ }^{1}$, Joachim Bischof ${ }^{1}{ }^{\mathbb{D}}$, Leiling Pan ${ }^{2}$, Franz Oswald ${ }^{2, *} \mathbb{C}$ and Uwe Knippschild ${ }^{1, * \mathbb{C}}$ \\ 1 University Medical Center Ulm, Department of General, and Visceral Surgery, University of Ulm, \\ Albert-Einstein-Allee 23, 89081 Ulm, Germany; aileen.roth@uni-ulm.de (A.R.); \\ adrian.gihring@uni-ulm.de (A.G.); joachim.bischof@uni-ulm.de (J.B.) \\ 2 University Medical Center Ulm, Center for Internal Medicine, Department of Internal Medicine I, \\ University of Ulm, Albert-Einstein-Allee 23, 89081 Ulm, Germany; leiling.pan@uni-ulm.de \\ * Correspondence: franz.oswald@uni-ulm.de (F.O.); uwe.knippschild@uniklinik-ulm.de (U.K.); \\ Tel.: +49-731-500-44544 (F.O.); +49-731-500-53580 (U.K.)
}

check for

updates

Citation: Roth, A.; Gihring, A.;

Bischof, J.; Pan, L.; Oswald, F.;

Knippschild, U. CK1 Is a Druggable

Regulator of Microtubule Dynamics

and Microtubule-Associated

Processes. Cancers 2022, 14, 1345.

https://doi.org/10.3390/

cancers14051345

Academic Editor:

Claudia M. Kowolik

Received: 2 February 2022

Accepted: 3 March 2022

Published: 5 March 2022

Publisher's Note: MDPI stays neutral with regard to jurisdictional claims in published maps and institutional affiliations.

Copyright: () 2022 by the authors. Licensee MDPI, Basel, Switzerland. This article is an open access article distributed under the terms and conditions of the Creative Commons Attribution (CC BY) license (https:// creativecommons.org/licenses/by/ $4.0 /)$.
Simple Summary: The Casein Kinase 1 (CK1) family of serine-threonine specific protein kinases regulates the activity of key regulatory proteins and signaling pathways being involved in embryonic development but also in the adult organism. Furthermore, it plays an important role in the regulation of proliferation, differentiation, apoptotic processes, circadian rhythm, chromosome segregation, and other microtubule-associated processes. Deregulation of CK1 expression and activity, as well as mutations in the coding region, contribute to the development of many human pathologies, including cancer. Alternations in the site-specific phosphorylation of $\alpha / \beta$-tubulin and microtubule-associated proteins affect microtubule stability, finally resulting in mitotic defects and genomic instability. Here we review our knowledge about CK1 functions in general and especially in chromosome segregation. Furthermore, an update in modulating CK1 activity by small molecule inhibitors and peptides specifically inhibiting CK1 protein interactions as new therapy concepts for the treatment of cancer will be discussed.

Abstract: Protein kinases of the Casein Kinase 1 family play a vital role in the regulation of numerous cellular processes. Apart from functions associated with regulation of proliferation, differentiation, or apoptosis, localization of several Casein Kinase 1 isoforms to the centrosome and microtubule asters also implicates regulatory functions in microtubule dynamic processes. Being localized to the spindle apparatus during mitosis Casein Kinase 1 directly modulates microtubule dynamics by phosphorylation of tubulin isoforms. Additionally, site-specific phosphorylation of microtubuleassociated proteins can be related to the maintenance of genomic stability but also microtubule stabilization/destabilization, e.g., by hyper-phosphorylation of microtubule-associated protein $1 \mathrm{~A}$ and RITA. Consequently, approaches interfering with Casein Kinase 1-mediated microtubule-specific functions might be exploited as therapeutic strategies for the treatment of cancer. Currently pursued strategies include the development of Casein Kinase 1 isoform-specific small molecule inhibitors and therapeutically useful peptides specifically inhibiting kinase-substrate interactions.

Keywords: Casein Kinase 1; CK1; RITA; microtubule dynamics; cell cycle progression; microtubule transport; microtubule-associated proteins; MAPs; mitotic spindle; tumorigenesis

\section{Introduction}

Microtubules are helical fibers with an outer diameter of approximately $25 \mathrm{~nm}$ that consist of tubulin subunits (heterodimer of $\alpha$ - and $\beta$-tubulin) [1]. They present one of the main components of the eukaryotic cytoskeleton responsible for cell stability but also play a critical role in cell motility, intracellular transport, and mitosis [2]. Microtubules are organized by microtubule-organizing centers (MTOCs), including centrosomes, which serve as important nucleating factors that initiate microtubule polymerization $[3,4]$. The 
centrosome consists of two centrioles, surrounded by the pericentriolar material (PCM), which contains components such as $\gamma$-tubulin, which is important for anchoring and nucleating cytoplasmic microtubules to build up the mitotic spindle during cell division [5]. The mitotic spindle is organized by more than 1000 microtubule-associated proteins (MAPs), indispensable for the controlled regulation of the mitotic spindle [6].

If mitotic processes are not proceeding correctly, unequal distribution of chromosomes to the daughter cells and aneuploidy could have severe consequences, which might exert tumor-promoting functions. Therefore, mitosis needs to be strictly regulated and controlled. These regulatory processes are mainly driven by components of the mitotic kinome, including several kinase families such as NIMA-related kinases (Neks), cyclin-dependent kinases (CDKs), Polo-like kinases (Plks), and Aurora kinases, as well as phosphatases and kinase inhibitors [7]. More than 1000 phosphoproteins have been detected to be regulated in a cell cycle-dependent manner, and site-specific phosphorylation (in-) activates mitotic proteins or might even target them for degradation $[8,9]$.

Major kinases regulating the microtubule network belong to the Aurora and Plk families. The primary function of Aurora kinases is the control of cell division. Two pools of Aurora A (AurA) are involved in the regulation of mitosis: a first one supporting centrosome maturation in the G2 stage of the cell cycle and a second one supporting assembly and proper function of the bipolar spindle by associating with centrosome-proximal microtubules in metaphase [10]. Aurora B (AurB) and Aurora C (AurC) are involved in chromosome condensation, kinetochore attachment, and alignment of chromosomes in later stages of mitosis [11]. In several aneuploid human tumors (including breast, colorectal, hepatic, lung, and oral cancer), amplification, overexpression, or hyperactivation of AurA and AurB can be found; however, high levels of AurB might rather be a consequence than the cause of malignant transformation [12-14]. Similar to Aurora kinases, Plks are also involved in the regulation of cell division by controlling essential mitotic processes. Plk1 and Plk4 are the most studied Plks, and while Plk1 regulates centrosome maturation, spindle formation, and cytokinesis, Plk4 is important for controlling centriole division [15,16]. Apart from the regulation of centrosome- and spindle-associated processes, Plk1 is also able to phosphorylate p53, thereby initiating its degradation [17].

Besides Aurora kinases and Plks, CDKs and Neks also play critical roles in cell cycle regulation by phosphorylating multiple mitosis-related substrates. CDKs are known to be activated at each stage of the cell cycle by the formation of stage-specific cyclin/CDK complexes [18]. After activation, cyclin/CDK complexes promote DNA replication, centrosome duplication, spindle formation, and other cell cycle-associated processes by the phosphorylation of mitotic key regulators [19]. Members of the Nek family are initially characterized by their function in the regulation of mitosis, primarily including DNA damage response, cell cycle regulation, and centrosome organization [20-25].

In addition to the abovementioned kinase families, members of the CK 1 family of protein kinases are also known to be involved in the regulation of mitotic processes. The CK1 family is evolutionary highly conserved, ubiquitously expressed, and constitutes one of the first serine/threonine-specific protein kinases discovered [26,27]. The CK1 isoforms $\alpha, \beta, \gamma 1, \gamma 2, \gamma 3, \delta, \varepsilon$, together with the closely related Tau Tubulin Kinase 1 (TTBK1) and the Vaccine-related kinases (VRKs), form their own independent branch of the kinome tree of eukaryotic protein kinases [28,29]. Due to their wide range of substrates, CK1 isoforms are involved in many developmental pathways, including Wnt (Wingless/Int-1), Hh (Hedgehog), and Hippo signaling pathways, which are important in growth, homeostasis, and tissue development. Mutations of components and aberrant regulation of these pathways have been connected to various cancer entities [26,30]. The following section concentrates on the current knowledge of the contribution of CK1 in tumorigenesis and tumor progression. 


\section{Participation of CK1 in Tumorigenesis and Tumor Progression}

Cancer-related functions of the CK1 family are closely connected to the role of CK1 in the abovementioned signaling pathways. Besides that, numerous studies substantiated the oncogenic potential of CK1 by findings that $\mathrm{CK} 1$ isoforms modulate key regulatory proteins such as $\beta$-catenin, MDM2, and p53, which can be seen as crucial regulators in tumorigenesis [26,27]. So far, various mutations within CSNK1D encoding for CK1 $\delta$ have been identified and observed in different types of cancer. According to cBioPortal for Cancer Genomics, 852 different mutations have been reported in a curated set of 202 nonredundant studies (including 90,279 samples) (Figure 1 and Table 1).

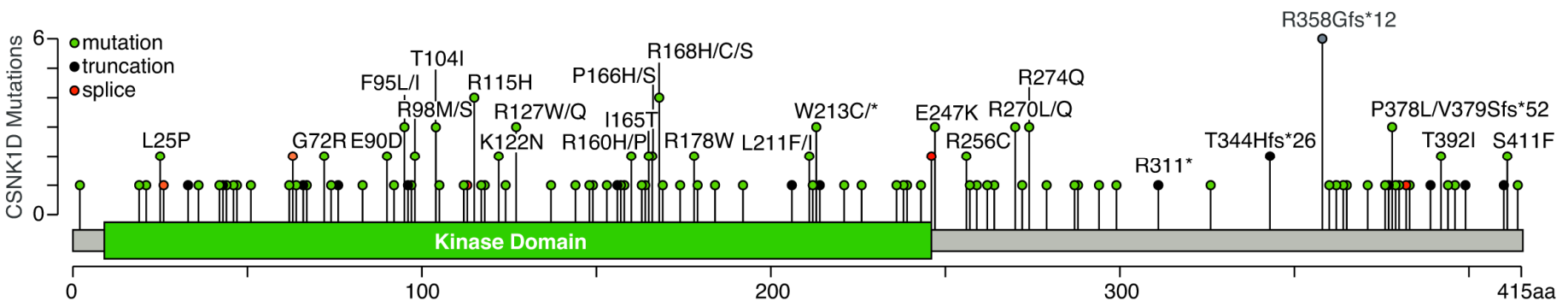

Figure 1. Mutations in CSNK1D (CK1ס). According to cBioPortal for Cancer Genomics, 852 different mutations have been reported in a curated set of 202 nonredundant studies, including 90,279 samples [31,32]. Positions of mutations in the CK1 $\delta$ protein are shown. Highlighted mutations $(n>1)$ and tumor samples are summarized in Table 1. Amino acids are shown in one-letter code. Abbreviations: aa-amino acids, * — stop codon, fs-frame shift.

Table 1. Highlighted mutations $(n>1)$ in CSNK1D and the respective cancer samples.

\begin{tabular}{ll}
\hline Mutation & Cancer \\
\hline L25P & Lung Adenocarcinoma, Stomach Adenocarcinoma \\
G72R & Uterine Endometrioid Carcinoma, Colorectal Adenocarcinoma \\
E90D & Uterine Endometrioid Carcinoma, Lung Adenocarcinoma \\
F95I & Cutaneous Melanoma \\
F95L & Mucinous Adenocarcinoma of the Colon and Rectum (2×) \\
R98M & Mucinous Adenocarcinoma of the Colon and Rectum \\
R98S & Serous Ovarian Cancer \\
T104I & Cutaneous Squamous Cell Carcinoma, Skin Cancer, Non-Melanoma \\
T104Pfs $* 9$ & Uterine Endometrioid Carcinoma \\
R115H & Colon Adenocarcinoma, Head and Neck Squamous Cell Carcinoma, Uterine \\
K122N & Endometrioid Carcinoma, Colorectal Adenocarcinoma \\
R127W & Endometrial Carcinoma, Lung Adenocarcinoma \\
R127Q & Cervical Squamous Cell Carcinoma, Colorectal Adenocarcinoma \\
R160P & Bladder Urothelial Carcinoma \\
R160H & Colon Adenocarcinoma \\
I165T & Colorectal Adenocarcinoma \\
P166H & Colorectal Adenocarcinoma, Intestinal Type Stomach Adenocarcinoma \\
P166S & Cutaneous Melanoma \\
R168S & Glioblastoma \\
R168C & Acute Myeloid Leukemia \\
R168H & Skin Cancer, Non-Melanoma \\
R178W & Uterine Endometrioid Carcinoma, Melanoma \\
L211F & Prostate, Colorectal Adenocarcinoma \\
L211I & Lung Adenocarcinoma \\
W213C & Uterine Serous Carcinoma/Uterine Papillary Serous Carcinoma \\
W213* & Cutaneous Squamous Cell Carcinoma, Melanoma \\
\hline & Lung Adenocarcinoma \\
\hline
\end{tabular}


Table 1. Cont.

\begin{tabular}{ll}
\hline Mutation & Cancer \\
\hline S246= & Breast Invasive Lobular Carcinoma, Cutaneous Squamous Cell Carcinoma \\
E247K & Rectal Adenocarcinoma, Uterine Endometrioid Carcinoma $(2 \times)$ \\
R256C & Angiosarcoma, Intestinal Type Stomach Adenocarcinoma \\
R270L & Cutaneous Melanoma $(2 \times)$ \\
R270Q & Cutaneous Melanoma \\
R274Q & Colon Adenocarcinoma, Uterine Serous Carcinoma/Uterine Papillary Serous \\
T344Hfs*26 & Carcinoma, Uterine Endometrioid Carcinoma \\
R358Gfs*12 & Colon Adenocarcinoma, Mucinous Adenocarcinoma of the Colon and Rectum \\
P378L & Squamous Cell Carcinoma \\
V379Sfs*52 & Greast Invasive Lobular Carcinoma \\
T392I & Stomach Adenocarcinoma $(2 \times)$ \\
S411F & Cutaneous Squamous Cell Carcinoma, Bladder Urothelial Carcinoma \\
\hline *-stop codon, =- splice mutation.
\end{tabular}

Although the mutation rate of CSNK1D is very low, a TCGA database analysis from certain tumor tissues and tumor cell lines clearly indicates genomic amplification of CSNK1D with the highest frequency in lung cancer and bladder/urinary tract cancer (Figure 2). Genomic alterations could explain that alterations in the expression levels in different cancer entities including urinary tract/bladder cancer [33], lung cancer [34], colorectal cancer [35], breast carcinomas [36], ductal pancreatic carcinomas [37], and blood cancer [38,39] (reviewed in $[40,41]$ ) contribute to tumorigenesis and tumor progression.

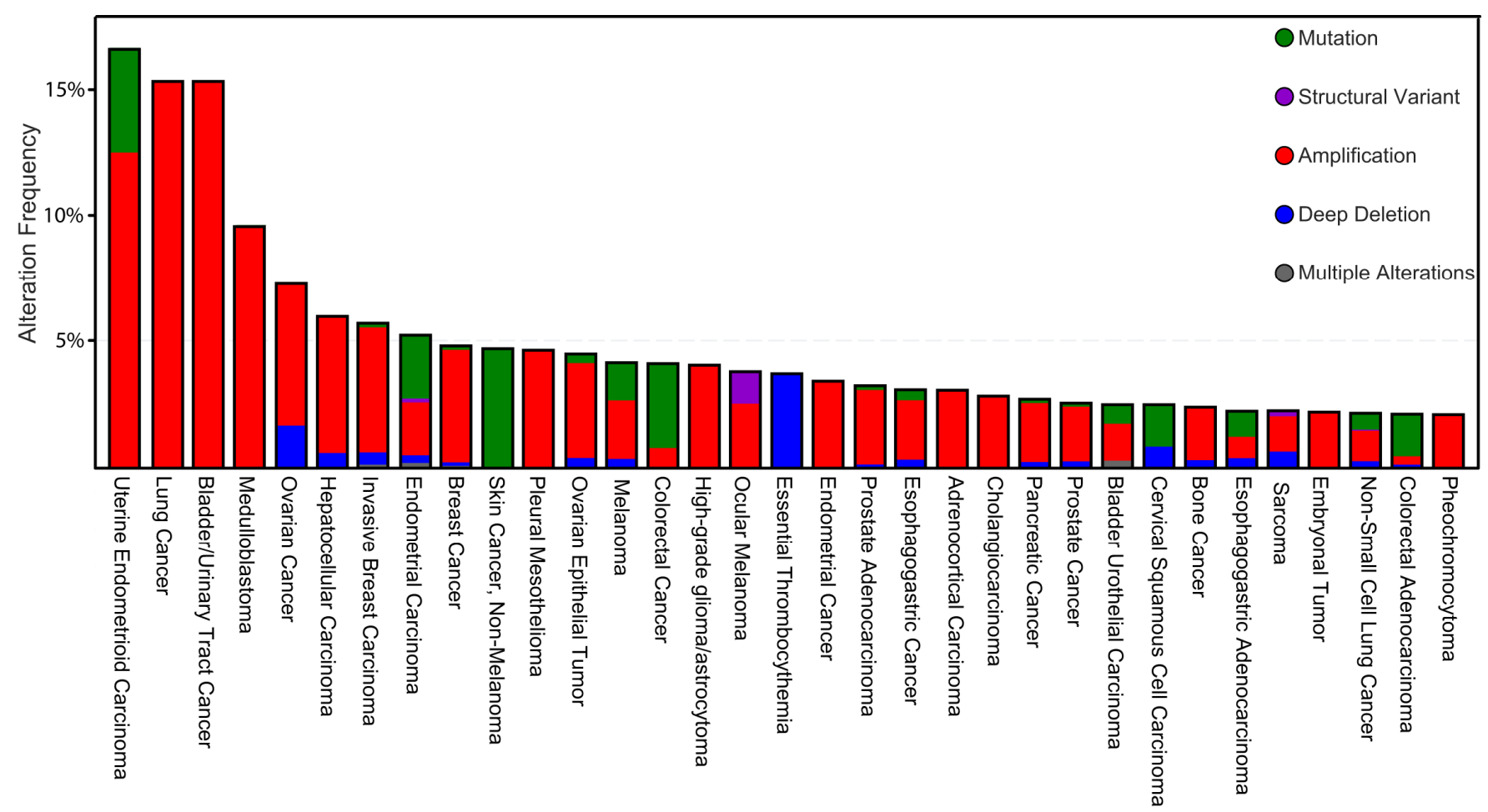

Figure 2. Genomic alternation frequencies and tumor types affecting the CSNK1D gene. 33 different tumor entities (Alternation Frequency $\geq 1 \%$ ) were analyzed using the cBioPortal for Cancer Genomics [31,32] accessing the actual TCGA dataset. The highest genomic amplification frequency for CSNK1D was detected in Lung Cancer and Bladder/Urinary Tract Cancer (approx. 15\%). 
Several studies provide evidence that the CK1 family exhibits oncogenic potential by promoting genome instability, promoting proliferation, and inhibiting apoptotic processes (reviewed in [42]), which is provoked by increased kinase activity caused by mutations in CSNK1D and, in particular, by overexpression of CK1ס in tumors.

Within the last few years, several CK1 isoforms were shown to be involved in the regulation of mitotic spindle organization and mitotic processes. Since cancer is characterized by uncontrolled cellular proliferation, which is caused by the aberrant activity of various cell cycle regulating proteins, cell cycle regulators, such as CK1, are seen as interesting targets in cancer therapy. A detailed presentation of CK1 isoforms in regulating cell cycle progression, modulating cytoskeleton components, and the role in microtubule transport will be described in detail in the following chapters.

\section{The Role of CK1 in Cell Cycle Progression}

Members of the CK1 family are known to be important regulators of genomic stability, microtubule dynamics, cell cycle progression, mitosis, and meiosis [43-54]. Interestingly, the Saccharomyces cerevisiae orthologue of CK18, Hrr25, was one of the first kinases being described to regulate cell cycle progression [55]. Recently, a study demonstrated that the inhibition of Hrr25 led to the assembly of unusually long cytoplasmic microtubules and incorrect spindle positioning [56]. P-bodies, cytoplasmic RNA-proteins (RNP), were found to provide protection for Hrr25 and CK1 in meiotic cells. Inhibition of this interaction led to decreased levels of Hrr25 and disturbed meiosis progression [57,58]. In addition to the S. cerevisiae orthologue Hrr25, the Schizosaccharomyces pombe orthologues of CK1, Hhp1, and Hhp2, have also been reported to be involved in the mitotic checkpoint by delaying cytokinesis under mitotic stress. In the context of these studies, it was shown that CK1 localizes to the spindle pole bodies (SPBs) and thereby phosphorylates septation initiation protein 4 (Sid4), leading to its degradation and cytokinesis suspension $[47,59]$.

Unfortunately, the precise contribution of each mammalian CK1 isoform to central functions in the regulation of the cell division cycle is not well understood. However, CK1 $\delta$ was shown to be associated with the centrosome, kinetochore, and microtubules, pointing to a cell cycle checkpoint control function of CK1 $[43,46]$. The hypothesis that CK1 fulfills regulatory roles at the centrosome is further supported by the findings that CK1 $\delta$ and CK1 $\varepsilon$ interact with the scaffold protein A-kinase anchor protein 450 (AKAP450). AKAP450 acts as an anchor point for CK1 $\delta$ at the centrosome enabling the CK1-mediated phosphorylation of the microtubule plus-end-binding protein 1 (EB1) and presenting a relevant factor for centrosome positioning during T cell activation [60] (Figure 3). Moreover, silencing of CK1 $\delta$ led to decreased expression of the cell division cycle 2 (CDC2)/CDK1 and checkpoint kinase (Chk)1, both being involved in mitotic checkpoints and DNA damage response [54]. Interaction of CK1 $1 \delta$ with Chk1 and Chk1-mediated regulation of CK1 $\delta$ activity have previously been shown [61]. Additionally, CK1 $\delta$-mediated degradation of Wee1-GC checkpoint kinase (Wee1) induced increased levels of active CDK1 and, thus, the entrance of cells into mitosis [50] (Figure 3). Interestingly, inhibition or depletion of CK1 $1 \delta$ provoked reduced Wee1 turnover, increased phosphorylation of CDK1, and, as a consequence, cell cycle exit $[49,50]$. However, it has still to be proven if the centrosomeassociated fraction of $\mathrm{CK} 1 \delta$ is involved in mediating this control. This assumption is supported by the fact that CK $1 \delta$-mediated phosphorylation of phosphoprimed Sid4, a scaffold protein and anchoring point of the spindle pole body in fission yeast, triggers the recruitment of Chk2/replication checkpoint kinase Cds1 [53] (Figure 3).

A far greater role with regard to spindle positioning and mitosis is played by $\mathrm{CK} 1 \alpha$. An immunohistological approach showed that $\mathrm{CK} 1 \alpha$ localizes to mitotic spindles [62], and injection of CK $1 \alpha$-specific morpholinos caused mitotic arrest and chromosomal misalignments in mouse oocytes [63]. A role in spindle positioning and cell division was shown for the interaction of $\mathrm{CK} 1 \alpha$ with the FAMily of sequence similarity (FAM)83 [64]. A recent study demonstrated that CK1 $\alpha$ is recruited to the mitotic spindle by FAM83D, and $\mathrm{CK} 1 \alpha$-binding deficient FAM83 ${ }^{\mathrm{F} 283 \mathrm{~A} / \mathrm{F} 283 \mathrm{~A}}$ knocking mutations exhibit prolonged 
mitosis and spindle positioning defects [65]. However, stronger interaction with CK1 $\alpha$ was observed for FAM83B, FAM83E, FAM83G, and FAM83H detected via immunoprecipitation and mass spectrometry [66]. Recently, a study assumed that mutations in FAM83G, more precisely in the conserved domain of unknown function 1669 (DUF1669), lead to disruption of CK1 $\alpha$ interaction and, thereby, attenuation of Wnt signaling [67]. Similar results have recently been shown for FAM110A. In this study, it was demonstrated that CK1 interacts with FAM110A during mitosis, and inhibition of CK1 or depletion of FAM110A, led to chromosomal alignment defects and delayed mitosis progression (Figure 3). Interestingly, defects in chromosomal alignment were rescued by mimicking phosphorylation with FAM110A-S252-255E mutants [68]. Functional binding partners of CK1, such as the anchoring proteins FAM83 and FAM110A, could be used as alternative targets in cancer treatment by blocking specifically the interaction of CK1 isoforms with these anchoring proteins and thus, inhibiting CK1 isoform-mediated substrate phosphorylation (see also Section 7.4) [68].

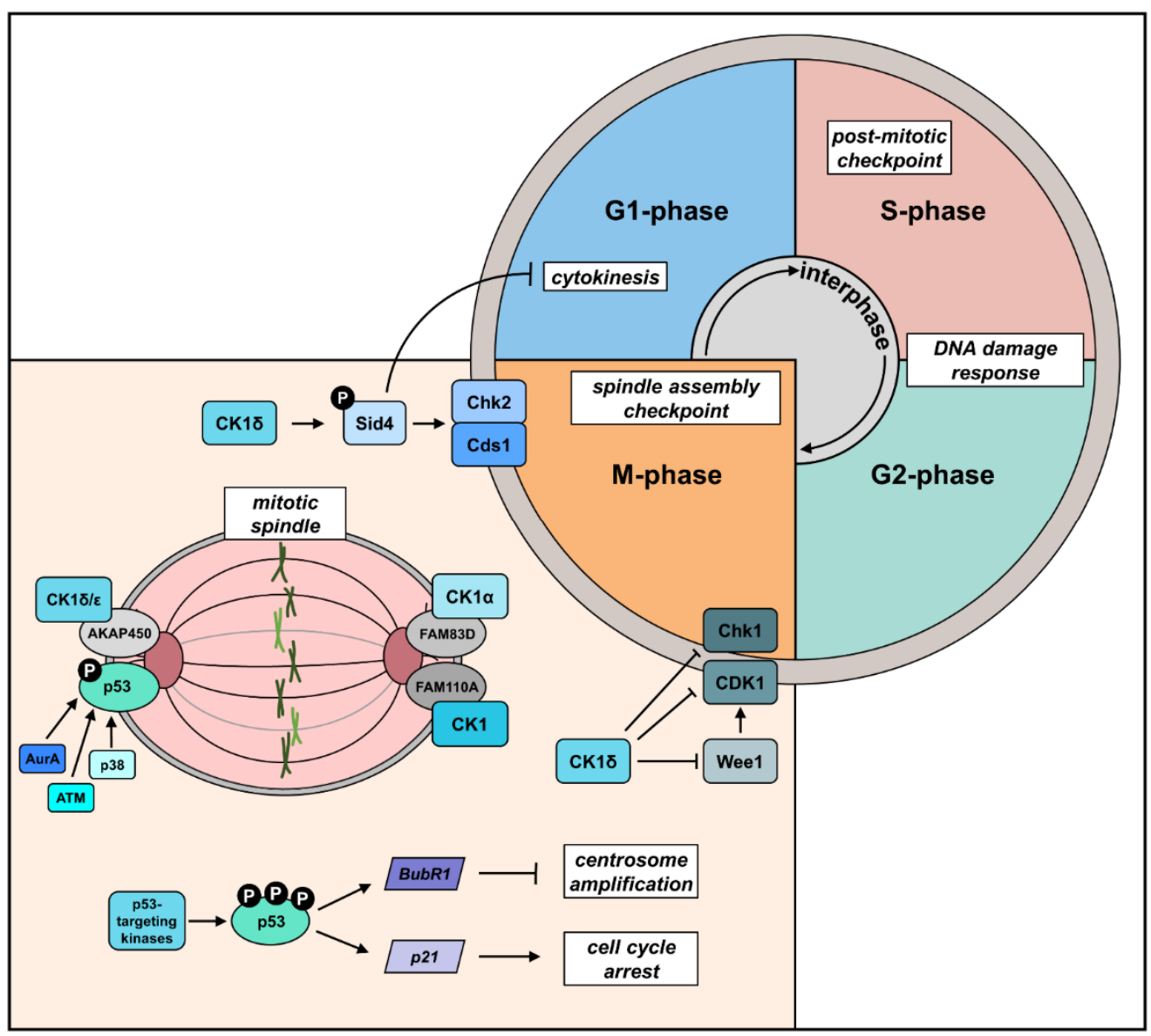

Figure 3. Cell cycle-associated functions of the CK1 family. CK1 localizes to spindle pole bodies and thereby phosphorylates Sid4 leading to its degeneration and delayed cytokinesis. Additionally, phosphorylation of Sid4 causes the recruitment of Chk2/replication checkpoint kinase Cds1, which supports the mitotic commitment. $\mathrm{CK} 1 \alpha, \mathrm{CK} 1 \delta$, and $\mathrm{CK} 1 \varepsilon$ are localized to the mitotic spindle mediated through the interaction with centrosome-associated proteins, such as AKAP450, FAM83D, and FAM110A. Site-specific phosphorylation of p53 leads to p53-dependent transcriptional activation of target genes such as p21 and BubR1 involved in the regulation of centrosomal functions, such as centrosome amplification and cell cycle arrest. Silencing of CK1 $1 \delta$ leads to decreased expression of CDK1 and Chk1, which are both involved in mitotic checkpoints and DNA damage response. Moreover, CK1 1 -mediated degradation of Wee1 increases levels of active CDK1 and, thus, initiate the entrance of cells into mitosis. Parts of the figure were generated using templates from Servier Medical Art [69], which is licensed under a Creative Commons Attribution 3.0 Unported License. 


\section{The Contribution of CK1 to the Modulation of Cytoskeleton Components}

Due to their numerous substrates, it is not surprising that CK1 isoforms have also been implicated in the modulation of microtubule polymerization, stability, and spindle dynamics linked to the direct phosphorylation of the microtubule subunits $\alpha-, \beta-$, and $\gamma$-tubulin $[44,46]$. In synchronized mitotic cells treated with DNA damaging agents (such as etoposide or camptothecin), the association of CK1 $\delta$ with $\alpha$ - and $\gamma$-tubulin increases [44], indicating its regulatory functions at the mitotic spindle. A function for CK1 in spindle association, microtubule modulation, and microtubule dynamics by phosphorylation of several MAPs, which have prognostic relevance for the overall survival of cancer patients, was also shown [65,70-73]. So far, several MAPs, such as MAP1A, MAP2, MAP4, stathmin and tau were discovered to be phosphorylated by CK1 [44,74-76] (Figure 4). The most studied CK1 interaction partner within the MAPs is the tau protein. Recent studies demonstrated the importance of CK1 isoforms in the abnormal hyperphosphorylation and deregulation of tau, finally leading to microtubule destabilization and neuronal cell death, which is associated with Alzheimer's disease [77]. Moreover, the involvement of tau in the regulation of cell migration has been reported by more recent studies and reviewed in [78]. Increased levels of tau phosphorylation in cancer cells, subsequent detachment of tau from microtubules, and its inability to perform microtubule-related functions have been described in several studies. Hyperphosphorylated tau has been detected in prostate and colon cancer cell lines. Additionally, increased levels of phospho-tau were shown to be a marker for nonmetastatic colon cancer [79-81].

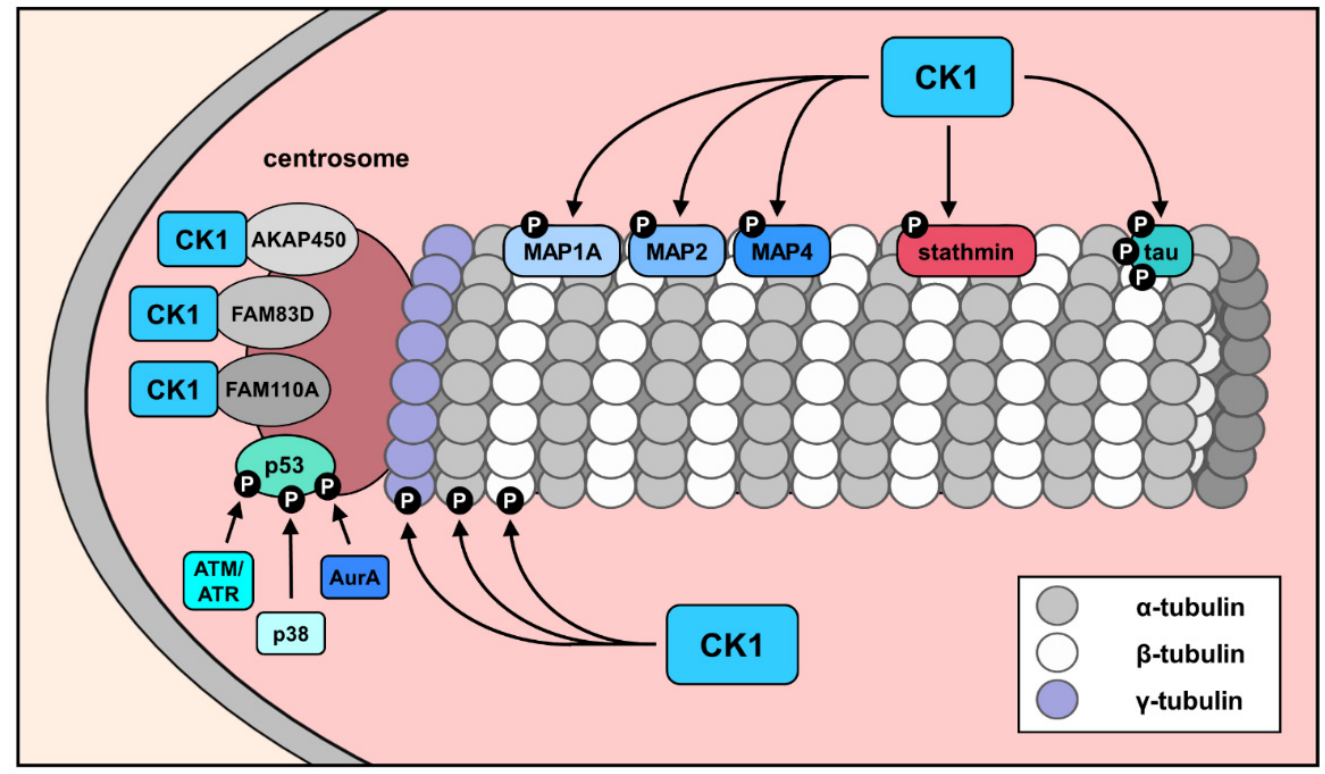

Figure 4. The role of CK1 in the modulation of cytoskeleton components. Direct CK1-mediated phosphorylation of microtubule subunits, such as $\alpha-, \beta-$, and $\gamma$-tubulin, leads to the modulation of microtubule polymerization, stability, and spindle dynamics. In addition, microtubule dynamics are also influenced by CK1-mediated phosphorylation of MAPs, such as MAP1A, MAP2, MAP4, stathmin, and tau [44,74-76] (Figure 4). Parts of the figure were generated using templates from Servier Medical Art [69], which is licensed under a Creative Commons Attribution 3.0 Unported License.

The involvement of CK1 in microtubule dynamics is also supported by the close connection of CK1 $\delta$ to microtubule-associated centrosomal subfraction of the tumor suppressor protein p53 [82-84] (Figure 4). Generally, p53 is involved in centrosome duplication and, therefore, protective against defective centrosome amplification and reduplication, preventing the occurrence of mitotic errors and the development of chromosomal instability [84-88]. In order to meet these demands, p53-dependent transcriptional activation 
of target genes, such as p21 and BubR1 (regulating centrosome functions) [89,90], as well as transcription-independent functions of p53, are required. The latter includes the ability of p53 to interact with several centrosome-associated proteins, such as $\gamma$-tubulin and centrin. These interactions appear to be necessary to maintain centrosome biogenesis [91]. Site-specific phosphorylation of p53 seems to play an important role in this function. Thus, phosphorylation of p53 at Ser15 is essential for colocalization with various centrosomal proteins, thereby contributing to the inhibition of uncontrolled centrosome duplication [92]. There is evidence that site-specific phosphorylation of p53 at Ser15, and Ser33 by centrosome-associated and stress-induced kinases, such as AurA, ATM/ATR, and p38, is required for the maintenance of centrosome homeostasis under normal and various stress conditions [87,93-96]. Furthermore, the ability of p53 to bind to unduplicated centrosomes depends on the phosphorylation of Ser315 by CDK2 and might also be important for p53-mediated regulation of centrosome duplication [84].

In addition, since both p53 and CK1 isoforms interact with the centrosome, new insights are needed concerning the role of $\mathrm{CK} 1 \delta / \varepsilon$-mediated site-specific phosphorylation of p53 in modulating the centrosomal functions of p53, such as the association of p53 with key centrosome factors necessary for inhibition of the duplication of centrioles [97]. A particular focus should also be placed on the implications of the functional significance of the interactions of CK1 $\delta$ with centrosomal p53, as there is evidence that CK $1 \delta$ and p53 are linked by an autoregulatory feedback loop [97].

\section{CK1-Associated Functions in Microtubule Transport}

CK1 plays a role in regulating cell cycle progression and the interactions between microtubules and membranes. In addition to that, several studies proposed that CK1 isoforms affect transport processes along microtubules. Recently, it was demonstrated that CK $1 \varepsilon$ is involved in the regulation of dynein-dependent transport processes by phosphorylation of the dynein intermediate chain component IC138, thereby inhibiting the minus-end directed transport of membrane organelles [98,99]. Interestingly, CK1 inhibitors rescued dynein activity, which was blocked by the phosphorylation of IC138. The hypothesis that CK1 has an inhibitory role in microtubule transport was also supported by the findings that solubilization of CK1 and the use of CK1-specific inhibitors restored microtubule sliding in pf17 (paralyzed flagellar mutant) axonemes [100].

\section{The MAP RITA as a Putative Target for CK1}

RITA (RBP interacting and tubulin-associated), a highly conserved $36 \mathrm{kDa}$ protein, was originally identified in a yeast to hybrid screen searching for novel RBPJ interacting proteins [101]. The transcription factor RBPJ also called RBP or CSL, is the central DNA-binding hub of the highly conserved Notch signaling pathway [102]. Notch signaling regulates fundamental cellular processes during embryonic development and in the adult organism. Aberrant Notch signaling results in severe congenital diseases and cancer $[103,104]$. After ligand binding to the Notch receptor, signal transduction involves the presenilin-dependent intracellular processing of the receptor and nuclear translocation of its intracellular domain (NICD). NICD associates with RBPJ and recruits coactivator complexes to activate transcription. In the absence of a Notch signal, RBPJ recruits corepressor complexes to shut down transcription [105].

RITA binds to the beta trefoil domain (BTD) of RBPJ, and in a recent structure-function analysis, we identified this type of interaction as a "RAM-Type" (Figure 5, upper middle panel) since it shows a striking similarity to the interaction of RBPJ with the RAM domain (RBPJ-associated molecule) of NICD [106] and now explains the mutually exclusive binding of either RITA or NICD to RBPJ on the structural level [107]. 

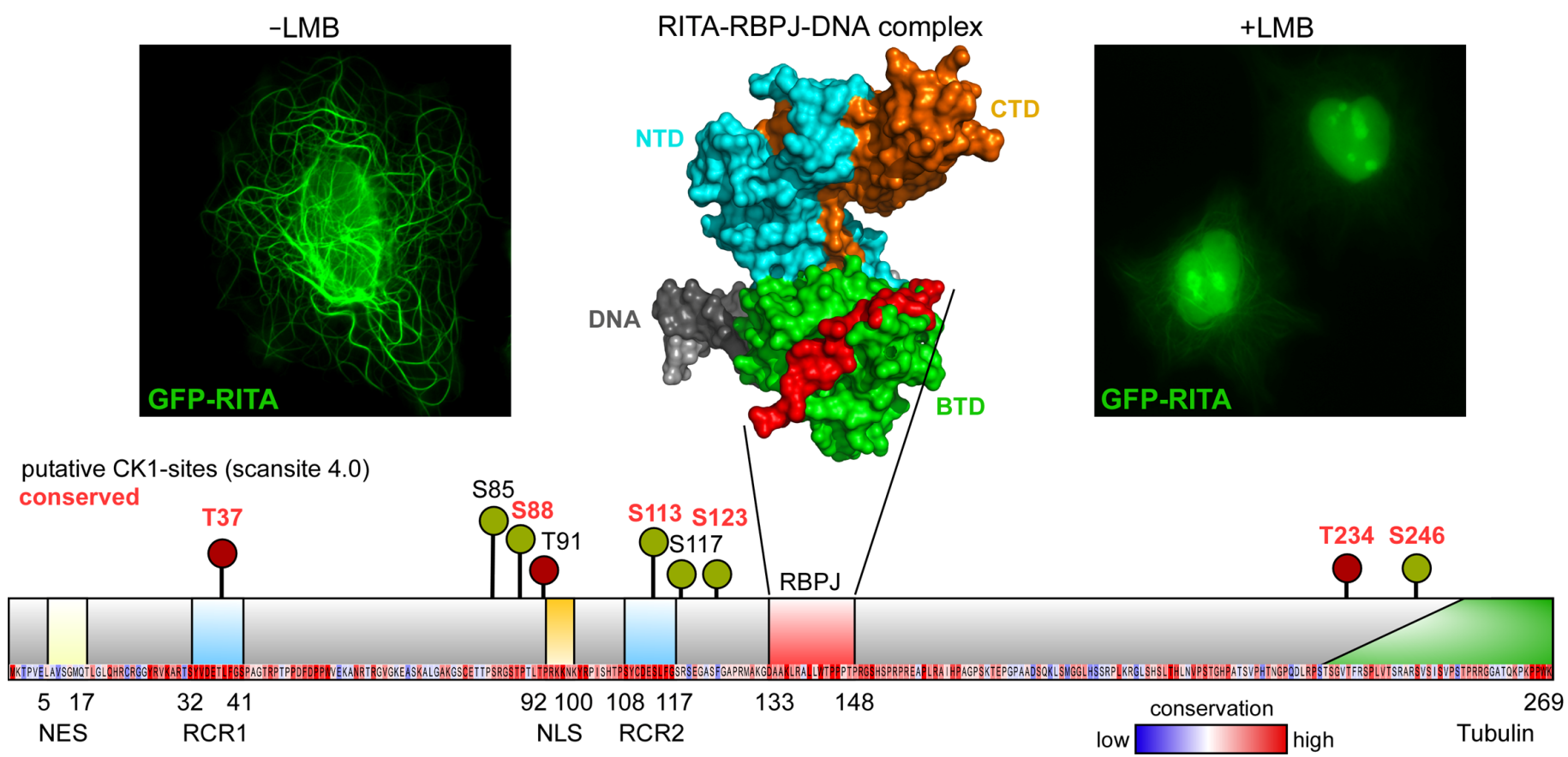

Figure 5. RITA is a tubulin- and RBPJ-binding shuttle protein with putative CK1 $\delta$ phosphorylation sites. GFP-RITA shows association to tubulin fibers (-LMB, left) and localizes to the nucleus after inhibition of nuclear export by leptomycin B (+LMB) (right). Structure of the DNA bound RBPJ-RITA complex (middle), (PDB-ID: 5EG6). RITA (red) interacts with the beta-trefoil domain (BTD, green) of RBPJ in a RAM-like association. Scansite 4.0 identifies several putative CK1 $1 \delta$ phosphorylation sites. Conserved sites in several species are marked in red. Human RITA is a $36 \mathrm{kDa}$ protein with 269 amino acid residues. Identified domains are specified. NES, nuclear export signal, RCR1 and 2, RITA conserved repeat 1 and 2, NLS, nuclear localization signal, RBPJ, RBPJ interaction domain, Tubulin, tubulin-binding domain. Conserved amino acid residues are shown under the schematic protein representation.

Further analysis revealed RITA not only interacts with RBPJ but also binds to tubulin in the cytoplasm and shuttles rapidly between the cytoplasm and the nucleus [101]. (Figure 5, upper left and right panel). We could identify and functionally characterize a nuclear export signal (NES) as well as a nuclear localization signal (NLS) and the tubulin-binding domain within the RITA proteins of various species (Figure 5, lower). Mechanistically, RITA interferes with RBPJ-NICD interaction and exports RBPJ from the nucleus to down-regulate Notch activity.

Interestingly, RITA-deficient mice show no obvious developmental defects, but aged animals develop tissue infiltrating lymphomas. In addition, RITA down-regulation was also found in hepatocellular carcinoma (HCC), suggesting that RITA might be a novel tumor suppressor [108,109].

In a recent study, we found that RITA localizes to interphase microtubules as well as to mitotic microtubule structures, thereby "bundles" the microtubules "thickened" fibers as shown by high-resolution microscopy. Cells deficient of RITA show altered microtubule stability together with highly acetylated $\alpha$-tubulin. Microtubule dynamics is reduced in cells after RITA knockdown as well as in RITA-deficient mouse embryonic fibroblasts (MEF), leading to mitotic defects such as chromosome segregation errors and chromosome misalignment.

From this study, it is suggested that RITA recruits histone deacetylase (HDAC)-6 to tubulin, and after knockdown of RITA, increased activity of microtubule-associated acetyltransferase Mec-17 leads to an increase of tubulin acetylation and stabilization [110]. Furthermore, RITA was shown to be involved in the activation of AurA kinase activ- 
ity at spindle poles [111] and in the regulation of cellular migration and invasion [112]. Thus, RITA might play a novel critical role in modulating microtubule dynamics, and its deregulation may contribute to chromosome instability and tumorigenesis.

To get a deeper insight into the regulation of RITA by posttranslational modifications, especially by phosphorylation, putative kinase target sites have been identified by Scansite 4.0 analysis [113]. Interestingly, a database search revealed various putative CK1 phosphorylation sites (Figure 5). Additional analyses are necessary to identify the exact phosphorylation sites of CK1 $1 \delta$ on RITA and the functional consequences. However, RITA might be an additional target of CK1 $\delta$ as shown for the MAPs MAP1A, MAP2, and MAP4 [44,74], and CK1 $\delta$-induced deregulation of RITA might also have an impact on tumor initiation and progression.

\section{Addressing Inhibition of Cell Division in Cancer Therapy}

\subsection{Microtubule-Targeting Agents}

Since the first approval of vinca alkaloids and taxanes for therapeutic application in the 1960s, the microtubule skeleton has emerged as an important target for anticancer therapy. Generally, two main categories of microtubule-targeting agents (MTAs) (also known as tubulin-binding agents, TBAs) can be distinguished: microtubule-stabilizing agents (MSAs), such as taxanes, increase the lateral interactions between the tubulin heterodimers, consequently resulting in increased polymerization and stabilization of microtubules. Microtubule-destabilizing agents (MDAs), such as colchicines and vinca alkaloids, lead to microtubule depolymerization by decreasing or inhibiting (mainly, but not only) longitudinal interactions between tubulin heterodimers. These MTAs interact with tubulin via six different binding sites. While the taxane, laulimalide/peloruside, vinca, and maytansine sites are located on $\beta$-tubulin, the colchicine site is located in proximity to the interface between the $\alpha$ - and $\beta$-subunits, and the pironetin site is located on the $\alpha$-tubulin subunit (reviewed in [114]). So far, various MTAs have been already approved or are currently in clinical investigation phases for cancer treatment (reviewed in [115]).

Most MTAs have been isolated from plant, fungi, or invertebrate origin with paclitaxel (isolated from Taxus brevifolia) [116], vinca alkaloids (discovered in Catharantus roseus (L.) G. Don) [117], and colchicine (isolated from autumn crocus Colchicum autumnale) [118] being the best-known MTA compounds. While the use of paclitaxel and vinca alkaloids in anticancer therapy is associated with severe side effects such as neurotoxicity, myelosuppression, or the development of multidrug resistance, the discovery of less toxic derivatives of these compounds enabled successful treatment of various cancers including breast, lung, bladder, prostate, and other cancers (reviewed in [119]). Due to its severe toxicity, neither colchicine nor any other colchicine-site MTA has been approved for cancer treatment so far, although some promising derivatives are currently under investigation in clinical trials [120]. New MTAs of natural or synthetic origin are still to be discovered and tested in (pre-) clinical investigation. Combretastatin and its analogs (such as Ombrabulin, first isolated from Combretum caffeum) demonstrated potent antitumor activity and safety in the treatment of ovarian cancer [121-124]. Epothilones belong to the microtubule-stabilizing group of MTAs, being first discovered as antifungal agents produced by Sorangium cellulolus ([125] and references therein). The mechanism of epothilones is similar to paclitaxel, and the epothilone derivative Ixabepilone has already been approved for the treatment of aggressive metastatic or locally advanced breast cancer $[126,127]$. The synthetic sulphonamide ABT-751 binds to the colchicine binding site on $\beta$-tubulin and inhibits microtubule polymerization. Significant anticancer effects, which have been demonstrated against non-small cell lung cancer and colon cancer, could be obtained by blocked cell cycle progression and induced apoptosis [128,129].

However, MTAs still present certain drawbacks, such as poor solubility, low bioavailability, toxicity, and multidrug resistance. Neurological side effects, including peripheral, cranial, and autonomic neuropathy as well as headache, dizziness, and mental depression, and hematologic side effects referred to as myelosuppression are the main toxicities 
associated with MTAs and often have dose-limiting consequences. Common side effects also include nausea, vomiting, and diarrhea [130]. Approaches to limit adverse events but also to overcome resistance, therefore, include combination therapy, e.g., paclitaxel and gemcitabine for the treatment of advanced pancreatic cancer [131] and numerous other combinations being currently under clinical investigation (reviewed by Nawara et al., [132]), as well as introducing novel antibody drug conjugates such as ado-trastuzumab emtansine (the maytansine derivative emtansine was conjugated to trastuzumab), which has recently been evaluated and approved for anticancer therapy [133]. As an alternative to directly targeting microtubules, an intervention on microtubule dynamics can also be achieved by targeting the mitotic kinome responsible for posttranslational modifications of microtubules or MAPs.

\subsection{Inhibitors Targeting the Mitotic Kinome}

The ATP-competitive AurA-selective inhibitor Alisertib (MLN8237) induces cell cycle arrest in the G2/M phase, apoptosis, and autophagy [134-137] (see Table 2). Alisertib prevents AurA-induced stabilization of N-Myc [138] and is currently under clinical investigation for the treatment of various malignancies, including neuroblastoma, small cell lung cancer, neurocrine prostate cancer, and breast cancer, among others [139-141]. The AurB-selective inhibitor Barasertib (AZD1152) inhibits tumor growth by decreasing histone phosphorylation resulting in the accumulation of aneuploidy cells and induction of apoptosis [142,143]. Cytotoxic effects of Barasertib might also be associated with stimulation of reactive oxygen species (ROS) production [144]. Barasertib has been tested in clinical trials for acute myeloid leukemia (AML) but induced severe side effects. Improved efficacy and tolerability are now expected for a new Barasertib nanoparticle formulation [145]. Apart from these compounds, a non-ATP-competitive inhibitor of AurA has also been described (AurkinA) binding to the Tpx2-binding surface of AurA and consequently displacing AurA from the mitotic spindle [146].

Volasertib, the most studied ATP-competitive inhibitor of Plk1, arrests cells in the G2/M phase and subsequently induces apoptosis [147,148]. Clinical trials demonstrated that Volasertib is more potently inhibiting the growth of hematopoietic malignancies in comparison with solid tumors [149].

Similar to Aurora kinases and Plks-and as introduced in the previous sectionsmembers of the CK1 family are also involved in regulating microtubule dynamics and mitotic processes via their interaction with centrosomes, the phosphorylation of microtubuleassociated cellular components, and their recruitment to the mitotic spindle apparatus. Therefore, also CK1 appears to be an attractive drug target for the induction of anti-cancer effects mediated by interference with microtubule-related processes. Since the association of CK1 $\delta$ is significantly enhanced by treatment of the cells with DNA damage induced by camptothecin, etoposide, or $\gamma$-irradiation [44], simultaneous treatment with CK1 $\delta$-specific inhibitors might have synergistic or additive effects. Pharmacological inhibition, as well as siRNA-induced knockdown of CK1 $1 \delta$, already demonstrated effective inhibition of primary ciliogenesis via negative regulation of centrosome-specific functions and inhibition of (AKAP450-dependent) microtubule nucleation at the Golgi apparatus [48]. However, the specific functions mediated by distinct CK1 isoforms and the effects of CK1 isoform-specific inhibition need to be investigated carefully in order to obtain the desired anticancer effects.

Furthermore, therapeutic effects could also be achieved by intervening with CK1mediated phosphorylation of MAPs such as Tau. Tau might be able to influence tumorigenesis by abnormal modulation of cell cycle progression, cell mobility, or organelle organization, and in fact, neurons from patients suffering from neurodegenerative diseases, including characteristic tau pathology, display hallmarks of DNA replication and active cell cycle as well as microtubule-mediated deformation of the nucleus [79-81]. Consequently, treatment with CK1-specific inhibitors (described in Table 2) could have therapeutic potential in cases where hyperphosphorylated tau can be linked to tumorigenesis, and reduction of Tau phosphorylation level has already been achieved by treatment of cells with CK1- 
specific inhibitors or CK1-specific siRNA [77,150]. In addition, more recently published potent CK1 isoform-selective small molecule inhibitors (SMIs) could prove to be therapeutically active (for review, see [41,42,151]). However, since treatment with CK1-specific inhibitors might improve tau binding to tubulin, these inhibitors may not be used together with taxanes because tau has been shown to interfere with the binding mode of taxanes to tubulin [152,153].

A special focus is given to the inhibitor IC261, which is one of the first potent SMI for CK1 first published in 2000, demonstrating obvious anticancer effects in subsequent studies within the following ten years $[37,46,154,155]$. However, it was observed that mitotic arrest in prometaphase and cytotoxicity is induced by CK1 $1 \delta$ - and $\varepsilon$-independent effects of IC261. In comparison with different compounds inducing prometaphase arrest, the effects induced by IC261 were similar to those observed for nocodazole and colchicine. Moreover, IC261 even competed with colchicine for its binding site on tubulin. Consequently, the cytotoxicity of IC261 can be attributed to the direct inhibition of microtubule polymerization rather than to the specific inhibition of CK1 $\delta$ and $\varepsilon$ [156]. These findings are supported by another study demonstrating that IC261-induced centrosome fragmentation during mitosis is independent of CK1 $\delta$ [157]. Microtubule depolymerization by IC261 can furthermore be antagonized by pretreatment of cells with the stabilizing agent paclitaxel. Lower concentrations of IC261 affected dynamics of mitotic spindles resulting in cell cycle arrest and apoptosis [158]. Structural alterations of the centrosomes, centrosome amplification with the formation of multipolar spindles, and the inhibition of mitosis have already been described earlier for trophoblast cells and murine tumor cells treated with IC261 [43,46]. Interactions between IC261 and tubulin have also been characterized by a cocrystallization study confirming that the binding of IC261 roughly overlaps the colchicine binding pose and represents a new colchicine site microtubule inhibitor [159].

Table 2. Overview of MTAs and inhibitors of microtubule- and MAP-associated protein kinases.

\begin{tabular}{|c|c|c|c|c|c|}
\hline Inhibitor & Target & Molecular/Therapeutic Effect & $\begin{array}{l}\text { Tumor } \\
\text { Entity }\end{array}$ & $\begin{array}{l}\text { Investigation } \\
\text { Phase }\end{array}$ & Ref. \\
\hline \multicolumn{6}{|c|}{ MSA-Taxol-domain binder } \\
\hline $\begin{array}{l}\text { Paclitaxel } \\
\text { Ixabepilone }\end{array}$ & $\beta$-tubulin & $\begin{array}{l}\text { Increase the lateral interactions between the tubulin } \\
\text { heterodimers resulting in increased polymerization } \\
\text { and stabilization of microtubules }\end{array}$ & $\begin{array}{l}\text { Ovarian and } \\
\text { breast cancer } \\
\text { Breast cancer }\end{array}$ & $\begin{array}{l}\text { Approved } \\
\text { Approved }\end{array}$ & $\begin{array}{c}{[160]} \\
{[126,127]}\end{array}$ \\
\hline \multicolumn{6}{|c|}{ MDA-Vinca-domain binder } \\
\hline $\begin{array}{l}\text { Vincristine } \\
\text { Vinblastine }\end{array}$ & $\beta$-tubulin & $\begin{array}{c}\text { Lead to microtubule depolymerization by decreasing } \\
\text { or inhibiting longitudinal interactions between } \\
\text { tubulin heterodimers }\end{array}$ & $\begin{array}{c}\text { Breast } \\
\text { cancer, } \\
\text { lymphomas } \\
\text { Lymphomas, } \\
\text { solid tumors }\end{array}$ & Approved & {$[161]$} \\
\hline \multicolumn{6}{|c|}{ MDA-Colchicine-domain binder } \\
\hline $\begin{array}{l}\text { Ombra- } \\
\text { bulin } \\
\text { ABT-751 }\end{array}$ & $\begin{array}{c}\text { Interface of } \\
\alpha-/ \beta \text {-tubulin }\end{array}$ & $\begin{array}{c}\text { Lead to microtubule depolymerization by decreasing } \\
\text { or inhibiting longitudinal interactions between } \\
\text { tubulin heterodimers }\end{array}$ & $\begin{array}{c}\text { Ovarian } \\
\text { cancer } \\
\text { Lung cancer, } \\
\text { colon cancer }\end{array}$ & $\begin{array}{l}\text { Stopped in } \\
\text { phase III } \\
\text { Phase II }\end{array}$ & $\begin{array}{c}{[124]} \\
{[128,129,162]}\end{array}$ \\
\hline \multicolumn{6}{|c|}{ Protein kinase inhibitors } \\
\hline Alisertib & AurA & $\begin{array}{c}\text { Induce cell cycle arrest in G2/M phase, apoptosis, } \\
\text { and autophagy; prevents AurA-induced stabilization } \\
\text { of N-Myc }\end{array}$ & $\begin{array}{l}\text { Leukemia, solid } \\
\text { tumors }\end{array}$ & Phase III & {$[134-141]$} \\
\hline AurkinA & AurA & $\begin{array}{c}\text { Bind to the Tpx2-binding surface of AurA and } \\
\text { consequently displacing AurA from the mitotic } \\
\text { spindle }\end{array}$ & - & Preclinical & [146] \\
\hline Barasertib & AurB & $\begin{array}{l}\text { Decrease histone phosphorylation resulting in } \\
\text { accumulation of aneuploidy cells and induction of } \\
\text { apoptosis; associated with stimulation of ROS }\end{array}$ & $\begin{array}{l}\text { Leukemia, solid } \\
\text { tumors }\end{array}$ & Phase II & {$[142-145]$} \\
\hline Volasertib & Plk1 & $\begin{array}{l}\text { Arrests cells in the G2/M phase and subsequently } \\
\text { induces apoptosis }\end{array}$ & Leukemia & Phase III & {$[147-149]$} \\
\hline
\end{tabular}


Table 2. Cont.

\begin{tabular}{|c|c|c|c|c|c|}
\hline Inhibitor & Target & Molecular/Therapeutic Effect & $\begin{array}{l}\text { Tumor } \\
\text { Entity }\end{array}$ & $\begin{array}{l}\text { Investigation } \\
\text { Phase }\end{array}$ & Ref. \\
\hline \multicolumn{6}{|c|}{ CK1-specific inhibitors } \\
\hline IC261 & $\begin{array}{l}\text { Initially designed for } \\
\text { CK1; } \\
\text { tubulin }\end{array}$ & $\begin{array}{l}\text { Binds to tubulin resulting in direct inhibition of } \\
\text { microtubule polymerization }\end{array}$ & Pancreatic cancer & Preclinical & $\begin{array}{l}{[37,46,154-} \\
159]\end{array}$ \\
\hline D4476 & $\mathrm{CK} 1 \alpha / \delta$ & $\begin{array}{l}\text { Inhibition of } \mathrm{CK} 1 \alpha / \delta \text { activity; sensitizes colorectal } \\
\text { cancer cells to } 5 \text {-fluorouracil }\end{array}$ & Colorectal cancer & Preclinical & {$[163]$} \\
\hline PF-670462 & $\mathrm{CK} 1 \delta / \varepsilon$ & Selective inhibition of CK $1 \delta / \varepsilon$ activity & Leukemia & Preclinical & {$[164,165]$} \\
\hline SR-3029 & $\mathrm{CK} 1 \delta / \varepsilon$ & Inhibition of overexpressed CK $1 \delta / \varepsilon$ & $\begin{array}{l}\text { Breast cancer, } \\
\text { skin tumor }\end{array}$ & Preclinical & {$[166,167]$} \\
\hline $\begin{array}{l}\text { IWP-2/IWP- } \\
\quad 4\end{array}$ & CK1 $1 \delta$ & Selective inhibition of $\mathrm{CK} 1 \delta$ & $\begin{array}{l}\text { Pancreatic, colon } \\
\text { cancer cell lines }\end{array}$ & Preclinical & {$[168]$} \\
\hline BTX-A51 & $\mathrm{CK} 1 \alpha / \delta / \varepsilon ; \mathrm{CDK} 7 / 9$ & $\begin{array}{l}\text { Inhibition of } \mathrm{CK} 1 \alpha \text { and activation of p53-dependent } \\
\text { cell death; inhibition of CDK7/9 }\end{array}$ & Leukemia & Phase I & {$[169]$} \\
\hline Lenalidomide & $\begin{array}{l}\text { CRL4 }{ }^{\text {CRBN }} \text { E3 } \\
\text { ubiquitin ligase; } \\
\text { indirectly CK1 } \alpha\end{array}$ & Induces ubiquitination and degradation of $\mathrm{CK} 1 \alpha$ & Leukemia & Approved & [170] \\
\hline Umbralisib & $\mathrm{PI} 3 \mathrm{~K} \delta ; \mathrm{CK} 1 \varepsilon$ & $\begin{array}{l}\text { Block the phosphorylation of eukaryotic translation } \\
\text { initiation factor } 4 \mathrm{E} \text { binding protein ( } 4 \mathrm{E}-\mathrm{BPI}) \text {, leading } \\
\text { to the inhibition of c-Myc translation and cell death }\end{array}$ & Lymphoma & Approved & {$[171,172]$} \\
\hline
\end{tabular}

\subsection{Combination of MTAs with Additional Anticancer Agents: Advantages of Dual-Specific Inhibitors}

The combination of MTAs with different anticancer agents, such as kinase inhibitors, HDACs, or DNA-damaging agents, represents an attractive antitumor strategy of the different mechanisms of action of the individual substances and the synergistic effects, which, however, often suffered setbacks in the past due to drug-drug interactions, complex application regimens, and poor patient compliance [173]. Inspired by the positive synergistic effects of multitarget strategies, dual target approaches, in particular, have been developed in recent years, largely overcoming the limitations of combination therapy and significantly reducing drug resistance and adverse effects. Dual targeting drugs are capable of interacting with two different drug targets. So far, numerous very effective synergistic dual inhibitors have been developed that interact with microtubule dynamics and with either kinases, heat shock proteins (HSPs), poly(ADP-ribose)-polymerases (PARPs), topoisomerases, HDACs, or estrogen receptors [174-178].

The development of highly potent dual-target drug inhibitors is most promising when functional interactions exist between the two target proteins. Thus, it is quite conceivable that the development of dual tubulin-CK1 $(\delta, \varepsilon$, or $\alpha)$ inhibitors will produce significantly better synergistic effects than the use of tubulin and CK1 isoform-specific inhibitors. This is also supported by the fact that CK1 isoforms phosphorylate tubulin and MAPs are involved in vesicle transport processes along microtubules, but are also associated with the mitotic spindle apparatus, especially in cellular stress situations such as toxin exposure, mechanical damage, environmental stress exposure [44] (reviewed in [42]).

\subsection{Modulation of the CK1 Activity with Biologicals}

Apart from CK1-specific SMIs, alternative therapeutic approaches such as therapeutic peptides might be used to modulate microtubule-associated processes. By using a CK1 1 derived peptide library, a CK1 $\delta$-derived peptide encompassing amino acids 361-375 of CK1ס (P39) was identified as a prominent binding partner for $\alpha$-tubulin. P39 inhibits phosphorylation of $\alpha$-tubulin by CK1 $\delta$ and blocks cell cycle progression of cells entering mitosis, finally leading to cell death [179]. In this context, identified peptides of a peptide library based on human CK1 $1 \delta$ and $C K 1 \varepsilon$ were used to block the interaction of CK1 $1 \delta / \varepsilon$ with the DEAD-box RNA helicase DDX3X, which was shown to stimulate CK1 activity and Wnt/ $\beta$-catenin signaling [180]. Mutations of DDX3X, which have been identified in medulloblastoma patients, increased the activity of CK1 in living cells, which led to 
aberrant stimulation of CK1-mediated pathways (such as Wnt/ $\beta$-catenin signaling) [181]. The identified interacting CK1 $/ \varepsilon$-derived peptides were shown to block the activation of CK1 $/ \varepsilon$ by DDX3X (probably caused by the inhibition of the activating interaction between both proteins) and inhibited the stimulation of CK1 activity in cell culture experiments [180].

The potential of interfering peptides was also shown by the modulation of the interaction of AXIN1-CK1 $\varepsilon$ and the regulation of CK1 1 -induced phosphorylation of disheveled (DVL) and the activation of the Wnt/ $\beta$-catenin signaling [182]. Furthermore, similar regulatory effects were shown for $\mathrm{CK} 1 \alpha$-derived peptides, which inhibit the interaction of CK1 $\alpha$ with MDM2 leading to reduced cell viability in a p53-dependent manner [183]. Biologicals, such as these identified interaction-blocking peptides, could therefore represent promising pharmacological tools for anticancer therapy.

\section{Conclusions}

The CK1 family of serine-threonine protein kinases has a major impact on multiple cellular functions during embryogenesis and in the adult organism. Due to its role in the regulation of tubulin dynamics by phosphorylation of multiple MAPs, the deregulation of CK1 leads to human diseases, including cancer. Modulating the activity of CK1 as a promising target against tumor progression could be an interesting therapeutic approach for a multidrug treatment against tumor development. Therefore, the development of CK1 (isoform)-specific inhibitors is essential and could offer an important contribution to personalized medicine. However, the development of optimized CK1 isoform-specific compounds available for in vivo application is still challenging and should include not only the use of conventional SMIs but also dual-specific inhibitors and inhibitory peptides.

Author Contributions: Conceptualization and supervision, J.B., F.O. and U.K.; writing-original draft preparation, review and editing, A.R., A.G., L.P., J.B., F.O. and U.K. All authors have read and agreed to the published version of the manuscript.

Funding: A.R., A.G. and L.P. are participating members of the International Graduate School in Molecular Medicine at Ulm University (IGradU), which is supported by the German Research Foundation (DFG) (grant number GSC 270). This work was further funded by the DFG (GRK2254/C4, SFB1074/A3, SFB1506/A5, OS 287/4-1) and the German Cancer Aid (Deutsche Krebshilfe) (\#70114289) to F.O. as well as the DFG (KN356/9-1) to U.K. and the Else Kröner-Fresenius-Stiftung (2017_A142) to J.B. and U.K.

Conflicts of Interest: The authors declare no conflict of interest.

\section{References}

1. Janke, C.; Magiera, M.M. The tubulin code and its role in controlling microtubule properties and functions. Nat. Rev. Mol. Cell Biol. 2020, 21, 307-326. [CrossRef] [PubMed]

2. Goodson, H.V.; Jonasson, E.M. Microtubules and Microtubule-Associated Proteins. Cold Spring Harb. Perspect. Biol. 2018, 10, a022608. [CrossRef] [PubMed]

3. Petry, S.; Vale, R.D. Microtubule nucleation at the centrosome and beyond. Nat. Cell Biol. 2015, 17, 1089-1093. [CrossRef] [PubMed]

4. Bornens, M. Centrosome organization and functions. Curr. Opin. Struct. Biol. 2021, 66, 199-206. [CrossRef]

5. Bettencourt-Dias, M.; Glover, D.M. Centrosome biogenesis and function: Centrosomics brings new understanding. Nat. Rev. Mol. Cell Biol. 2007, 8, 451-463. [CrossRef]

6. Petry, S. Mechanisms of Mitotic Spindle Assembly. Annu. Rev. Biochem. 2016, 85, 659-683. [CrossRef]

7. Crncec, A.; Hochegger, H. Triggering mitosis. FEBS Lett. 2019, 593, 2868-2888. [CrossRef]

8. Dephoure, N.; Zhou, C.; Villén, J.; Beausoleil, S.A.; Bakalarski, C.E.; Elledge, S.J.; Gygi, S.P. A quantitative atlas of mitotic phosphorylation. Proc. Natl. Acad. Sci. USA 2008, 105, 10762-10767. [CrossRef]

9. Ma, H.T.; Poon, R.Y.C. How protein kinases co-ordinate mitosis in animal cells. Biochem. J. 2011, 435, 17-31. [CrossRef]

10. Magnaghi-Jaulin, L.; Eot-Houllier, G.; Gallaud, E.; Giet, R. Aurora A Protein Kinase: To the Centrosome and Beyond. Biomolecules 2019, 9, 28. [CrossRef]

11. Willems, E.; Dedobbeleer, M.; Digregorio, M.; Lombard, A.; Lumapat, P.N.; Rogister, B. The functional diversity of Aurora kinases: A comprehensive review. Cell Div. 2018, 13, 7. [CrossRef]

12. Du, R.; Huang, C.; Liu, K.; Li, X.; Dong, Z. Targeting AURKA in Cancer: Molecular mechanisms and opportunities for Cancer therapy. Mol. Cancer 2021, 20, 15. [CrossRef] 
13. Ahmed, A.; Shamsi, A.; Mohammad, T.; Hasan, G.M.; Islam, A.; Hassan, M.I. Aurora B kinase: A potential drug target for cancer therapy. J. Cancer Res. Clin. Oncol. 2021, 147, 2187-2198. [CrossRef] [PubMed]

14. Borah, N.A.; Reddy, M.M. Aurora Kinase B Inhibition: A Potential Therapeutic Strategy for Cancer. Molecules 2021, $26,1981$. [CrossRef] [PubMed]

15. Habedanck, R.; Stierhof, Y.-D.; Wilkinson, C.J.; Nigg, E.A. The Polo kinase Plk4 functions in centriole duplication. Nat. Cell Biol. 2005, 7, 1140-1146. [CrossRef] [PubMed]

16. Maniswami, R.R.; Prashanth, S.; Karanth, A.V.; Koushik, S.; Govindaraj, H.; Mullangi, R.; Rajagopal, S.; Jegatheesan, S.K. PLK4: A link between centriole biogenesis and cancer. Expert Opin. Ther. Targets 2018, 22, 59-73. [CrossRef]

17. Yang, X.; Li, H.; Zhou, Z.; Wang, W.-H.; Deng, A.; Andrisani, O.; Liu, X. Plk1-mediated phosphorylation of Topors regulates p53 stability. J. Biol. Chem. 2009, 284, 18588-18592. [CrossRef]

18. Bertoli, C.; Skotheim, J.M.; de Bruin, R.A.M. Control of cell cycle transcription during G1 and S phases. Nat. Rev. Mol. Cell Biol. 2013, 14, 518-528. [CrossRef]

19. Bloom, J.; Cross, F.R. Multiple levels of cyclin specificity in cell-cycle control. Nat. Rev. Mol. Cell Biol. 2007, 8, 149-160. [CrossRef]

20. Melo-Hanchuk, T.D.; Slepicka, P.F.; Meirelles, G.V.; Basei, F.L.; Lovato, D.V.; Granato, D.C.; Pauletti, B.A.; Domingues, R.R.; Leme, A.F.P.; Pelegrini, A.L.; et al. NEK1 kinase domain structure and its dynamic protein interactome after exposure to Cisplatin. Sci. Rep. 2017, 7, 5445. [CrossRef]

21. Melo-Hanchuk, T.D.; Slepicka, P.F.; Pelegrini, A.L.; Menck, C.F.M.; Kobarg, J. NEK5 interacts with topoisomerase II $\beta$ and is involved in the DNA damage response induced by etoposide. J. Cell. Biochem. 2019, 120, 16853-16866. [CrossRef]

22. O'Regan, L.; Fry, A.M. The Nek6 and Nek7 protein kinases are required for robust mitotic spindle formation and cytokinesis. Mol. Cell. Biol. 2009, 29, 3975-3990. [CrossRef] [PubMed]

23. de Souza, E.E.; Meirelles, G.V.; Godoy, B.B.; Perez, A.M.; Smetana, J.H.C.; Doxsey, S.J.; McComb, M.E.; Costello, C.E.; Whelan, S.A.; Kobarg, J. Characterization of the human NEK7 interactome suggests catalytic and regulatory properties distinct from those of NEK6. J. Proteome Res. 2014, 13, 4074-4090. [CrossRef] [PubMed]

24. Prosser, S.L.; Sahota, N.K.; Pelletier, L.; Morrison, C.G.; Fry, A.M. Nek5 promotes centrosome integrity in interphase and loss of centrosome cohesion in mitosis. J. Cell Biol. 2015, 209, 339-348. [CrossRef] [PubMed]

25. Meirelles, G.V.; Perez, A.M.; de Souza, E.E.; Basei, F.L.; Papa, P.F.; Melo Hanchuk, T.D.; Cardoso, V.B.; Kobarg, J. “Stop Ne(c)king around": How interactomics contributes to functionally characterize Nek family kinases. World J. Biol. Chem. 2014, 5, 141-160. [CrossRef]

26. Schittek, B.; Sinnberg, T. Biological functions of casein kinase 1 isoforms and putative roles in tumorigenesis. Mol. Cancer 2014, 13, 231. [CrossRef]

27. Knippschild, U.; Gocht, A.; Wolff, S.; Huber, N.; Löhler, J.; Stöter, M. The casein kinase 1 family: Participation in multiple cellular processes in eukaryotes. Cell. Signal. 2005, 17, 675-689. [CrossRef] [PubMed]

28. Manning, G.; Whyte, D.B.; Martinez, R.; Hunter, T.; Sudarsanam, S. The protein kinase complement of the human genome. Science 2002, 298, 1912-1934. [CrossRef] [PubMed]

29. Ikezu, S.; Ikezu, T. Tau-tubulin kinase. Front. Mol. Neurosci. 2014, 7, 33. [CrossRef]

30. Shen, C.; Nayak, A.; Melendez, R.A.; Wynn, D.T.; Jackson, J.; Lee, E.; Ahmed, Y.; Robbins, D.J. Casein Kinase $1 \alpha$ as a Regulator of Wnt-Driven Cancer. Int. J. Mol. Sci. 2020, 21, 5940. [CrossRef]

31. Cerami, E.; Gao, J.; Dogrusoz, U.; Gross, B.E.; Sumer, S.O.; Aksoy, B.A.; Jacobsen, A.; Byrne, C.J.; Heuer, M.L.; Larsson, E.; et al. The cBio cancer genomics portal: An open platform for exploring multidimensional cancer genomics data. Cancer Discov. 2012, 2, 401-404. [CrossRef] [PubMed]

32. Gao, J.; Aksoy, B.A.; Dogrusoz, U.; Dresdner, G.; Gross, B.; Sumer, S.O.; Sun, Y.; Jacobsen, A.; Sinha, R.; Larsson, E.; et al. Integrative analysis of complex cancer genomics and clinical profiles using the cBioPortal. Sci. Signal. 2013, 6, pl1. [CrossRef] [PubMed]

33. Lin, Y.-C.; Chen, M.-C.; Hsieh, T.-H.; Liou, J.-P.; Chen, C.-H. CK1 $\delta$ as a potential therapeutic target to treat bladder cancer. Aging 2020, 12, 5764-5780. [CrossRef] [PubMed]

34. Bowman, B.M.; Sebolt, K.A.; Hoff, B.A.; Boes, J.L.; Daniels, D.L.; Heist, K.A.; Galbán, C.J.; Patel, R.M.; Zhang, J.; Beer, D.G.; et al. Phosphorylation of FADD by the kinase CK1 $\alpha$ promotes KRASG12D-induced lung cancer. Sci. Signal. 2015, 8, ra9. [CrossRef]

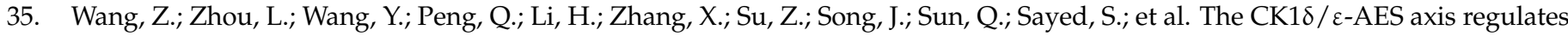
tumorigenesis and metastasis in colorectal cancer. Theranostics 2021, 11, 4421-4435. [CrossRef]

36. Shin, S.; Wolgamott, L.; Roux, P.P.; Yoon, S.-O. Casein kinase $1 \varepsilon$ promotes cell proliferation by regulating mRNA translation. Cancer Res. 2014, 74, 201-211. [CrossRef] [PubMed]

37. Brockschmidt, C.; Hirner, H.; Huber, N.; Eismann, T.; Hillenbrand, A.; Giamas, G.; Radunsky, B.; Ammerpohl, O.; Bohm, B.; Henne-Bruns, D.; et al. Anti-apoptotic and growth-stimulatory functions of CK1 delta and epsilon in ductal adenocarcinoma of the pancreas are inhibited by IC261 in vitro and in vivo. Gut 2008, 57, 799-806. [CrossRef]

38. Kaucká, M.; Plevová, K.; Pavlová, S.; Janovská, P.; Mishra, A.; Verner, J.; Procházková, J.; Krejcí, P.; Kotasková, J.; Ovesná, P.; et al. The planar cell polarity pathway drives pathogenesis of chronic lymphocytic leukemia by the regulation of B-lymphocyte migration. Cancer Res. 2013, 73, 1491-1501. [CrossRef]

39. Janovská, P.; Normant, E.; Miskin, H.; Bryja, V. Targeting Casein Kinase 1 (CK1) in Hematological Cancers. Int. J. Mol. Sci. 2020, 21, 9026. [CrossRef] 
40. Spinello, Z.; Fregnani, A.; Quotti Tubi, L.; Trentin, L.; Piazza, F.; Manni, S. Targeting Protein Kinases in Blood Cancer: Focusing on CK1 $\alpha$ and CK2. Int. J. Mol. Sci. 2021, 22, 3716. [CrossRef]

41. Xu, P.; Ianes, C.; Gärtner, F.; Liu, C.; Burster, T.; Bakulev, V.; Rachidi, N.; Knippschild, U.; Bischof, J. Structure, regulation, and (patho-)physiological functions of the stress-induced protein kinase CK1 delta (CSNK1D). Gene 2019, 715, 144005. [CrossRef] [PubMed]

42. Knippschild, U.; Krüger, M.; Richter, J.; Xu, P.; García-Reyes, B.; Peifer, C.; Halekotte, J.; Bakulev, V.; Bischof, J. The CK1 Family: Contribution to Cellular Stress Response and Its Role in Carcinogenesis. Front. Oncol. 2014, 4, 96. [CrossRef] [PubMed]

43. Behrend, L.; Milne, D.M.; Stöter, M.; Deppert, W.; Campbell, L.E.; Meek, D.W.; Knippschild, U. IC261, a specific inhibitor of the protein kinases casein kinase 1-delta and -epsilon, triggers the mitotic checkpoint and induces p53-dependent postmitotic effects. Oncogene 2000, 19, 5303-5313. [CrossRef]

44. Behrend, L.; Stöter, M.; Kurth, M.; Rutter, G.; Heukeshoven, J.; Deppert, W.; Knippschild, U. Interaction of casein kinase 1 delta (CK1ס) with post-Golgi structures, microtubules and the spindle apparatus. Eur. J. Cell Biol. 2000, 79, 240-251. [CrossRef]

45. Sillibourne, J.E.; Milne, D.M.; Takahashi, M.; Ono, Y.; Meek, D.W. Centrosomal anchoring of the protein kinase CK1delta mediated by attachment to the large, coiled-coil scaffolding protein CG-NAP/AKAP450. J. Mol. Biol. 2002, 322, 785-797. [CrossRef]

46. Stöter, M.; Bamberger, A.-M.; Aslan, B.; Kurth, M.; Speidel, D.; Löning, T.; Frank, H.-G.; Kaufmann, P.; Löhler, J.; Henne-Bruns, D.; et al. Inhibition of casein kinase I delta alters mitotic spindle formation and induces apoptosis in trophoblast cells. Oncogene 2005, 24, 7964-7975. [CrossRef]

47. Johnson, A.E.; Chen, J.-S.; Gould, K.L. CK1 is required for a mitotic checkpoint that delays cytokinesis. Curr. Biol. 2013, 23, 1920-1926. [CrossRef]

48. Greer, Y.E.; Westlake, C.J.; Gao, B.; Bharti, K.; Shiba, Y.; Xavier, C.P.; Pazour, G.J.; Yang, Y.; Rubin, J.S. Casein kinase $1 \delta$ functions at the centrosome and Golgi to promote ciliogenesis. Mol. Biol. Cell 2014, 25, 1629-1640. [CrossRef]

49. Penas, C.; Govek, E.-E.; Fang, Y.; Ramachandran, V.; Daniel, M.; Wang, W.; Maloof, M.E.; Rahaim, R.J.; Bibian, M.; Kawauchi, D.; et al. Casein kinase $1 \delta$ is an APC/C(Cdh1) substrate that regulates cerebellar granule cell neurogenesis. Cell Rep. 2015, 11, 249-260. [CrossRef]

50. Penas, C.; Ramachandran, V.; Simanski, S.; Lee, C.; Madoux, F.; Rahaim, R.J.; Chauhan, R.; Barnaby, O.; Schurer, S.; Hodder, P.; et al. Casein kinase 1ס-dependent Wee1 protein degradation. J. Biol. Chem. 2014, 289, 18893-18903. [CrossRef]

51. Phadnis, N.; Cipak, L.; Polakova, S.; Hyppa, R.W.; Cipakova, I.; Anrather, D.; Karvaiova, L.; Mechtler, K.; Smith, G.R.; Gregan, J. Casein Kinase 1 and Phosphorylation of Cohesin Subunit Rec11 (SA3) Promote Meiotic Recombination through Linear Element Formation. PLoS Genet. 2015, 11, e1005225. [CrossRef]

52. Sakuno, T.; Watanabe, Y. Phosphorylation of cohesin Rec11/SA3 by casein kinase 1 promotes homologous recombination by assembling the meiotic chromosome axis. Dev. Cell 2015, 32, 220-230. [CrossRef]

53. Chan, K.Y.; Alonso-Nuñez, M.; Grallert, A.; Tanaka, K.; Connolly, Y.; Smith, D.L.; Hagan, I.M. Dialogue between centrosomal entrance and exit scaffold pathways regulates mitotic commitment. J. Cell Biol. 2017, 216, 2795-2812. [CrossRef]

54. Greer, Y.E.; Gao, B.; Yang, Y.; Nussenzweig, A.; Rubin, J.S. Lack of Casein Kinase 1 Delta Promotes Genomic Instability-The Accumulation of DNA Damage and Down-Regulation of Checkpoint Kinase 1. PLoS ONE 2017, 12, e0170903. [CrossRef] [PubMed]

55. Hoekstra, M.F.; Liskay, R.M.; Ou, A.C.; DeMaggio, A.J.; Burbee, D.G.; Heffron, F. HRR25, a putative protein kinase from budding yeast: Association with repair of damaged DNA. Science 1991, 253, 1031-1034. [CrossRef] [PubMed]

56. Peng, Y.; Moritz, M.; Han, X.; Giddings, T.H.; Lyon, A.; Kollman, J.; Winey, M.; Yates, J.; Agard, D.A.; Drubin, D.G.; et al. Interaction of CK1 $\delta$ with $\gamma$ TuSC ensures proper microtubule assembly and spindle positioning. Mol. Biol. Cell 2015, 26, 2505-2518. [CrossRef] [PubMed]

57. Zhang, B.; Shi, Q.; Varia, S.N.; Xing, S.; Klett, B.M.; Cook, L.A.; Herman, P.K. The Activity-Dependent Regulation of Protein Kinase Stability by the Localization to P-Bodies. Genetics 2016, 203, 1191-1202. [CrossRef] [PubMed]

58. Zhang, B.; Butler, A.M.; Shi, Q.; Xing, S.; Herman, P.K. P-Body Localization of the Hrr25/Casein Kinase 1 Protein Kinase Is Required for the Completion of Meiosis. Mol. Cell. Biol. 2018, 38. [CrossRef] [PubMed]

59. Elmore, Z.C.; Guillen, R.X.; Gould, K.L. The kinase domain of CK1 enzymes contains the localization cue essential for compartmentalized signaling at the spindle pole. Mol. Biol. Cell 2018, 29, 1664-1674. [CrossRef] [PubMed]

60. Zyss, D.; Ebrahimi, H.; Gergely, F. Casein kinase I delta controls centrosome positioning during T cell activation. J. Cell Biol. 2011, 195, 781-797. [CrossRef]

61. Bischof, J.; Randoll, S.-J.; Süßner, N.; Henne-Bruns, D.; Pinna, L.A.; Knippschild, U. CK1 $\delta$ kinase activity is modulated by Chk1-mediated phosphorylation. PLoS ONE 2013, 8, e68803. [CrossRef] [PubMed]

62. Brockman, J.L.; Gross, S.D.; Sussman, M.R.; Anderson, R.A. Cell cycle-dependent localization of casein kinase I to mitotic spindles. Proc. Natl. Acad. Sci. USA 1992, 89, 9454-9458. [CrossRef]

63. Wang, L.; Lu, A.; Zhou, H.-X.; Sun, R.; Zhao, J.; Zhou, C.-J.; Shen, J.-P.; Wu, S.-N.; Liang, C.-G. Casein kinase 1 alpha regulates chromosome congression and separation during mouse oocyte meiotic maturation and early embryo development. PLoS ONE 2013, 8, e63173. [CrossRef] [PubMed]

64. Fulcher, L.J.; Sapkota, G.P. Mitotic kinase anchoring proteins: The navigators of cell division. Cell Cycle 2020, 19, 505-524. [CrossRef] [PubMed] 
65. Fulcher, L.J.; He, Z.; Mei, L.; Macartney, T.J.; Wood, N.T.; Prescott, A.R.; Whigham, A.J.; Varghese, J.; Gourlay, R.; Ball, G.; et al. FAM83D directs protein kinase CK1 $\alpha$ to the mitotic spindle for proper spindle positioning. EMBO Rep. 2019, 20, e47495. [CrossRef]

66. Fulcher, L.J.; Bozatzi, P.; Tachie-Menson, T.; Wu, K.Z.L.; Cummins, T.D.; Bufton, J.C.; Pinkas, D.M.; Dunbar, K.; Shrestha, S.; Wood, N.T.; et al. The DUF1669 domain of FAM83 family proteins anchor casein kinase 1 isoforms. Sci. Signal. 2018, 11, eaao2341. [CrossRef]

67. Wu, K.Z.L.; Jones, R.A.; Tachie-Menson, T.; Macartney, T.J.; Wood, N.T.; Varghese, J.; Gourlay, R.; Soares, R.F.; Smith, J.C.; Sapkota, G.P. Pathogenic FAM83G palmoplantar keratoderma mutations inhibit the PAWS1:CK1 $\alpha$ association and attenuate Wnt signalling. Wellcome Open Res. 2019, 4, 133. [CrossRef]

68. Aquino Perez, C.; Burocziova, M.; Jenikova, G.; Macurek, L. CK1-mediated phosphorylation of FAM110A promotes its interaction with mitotic spindle and controls chromosomal alignment. EMBO Rep. 2021, 22, e51847. [CrossRef]

69. Servier Medical Art. SMART-Servier Medical ART. Available online: https:/ / smart.servier.com/ (accessed on 25 January 2022).

70. Brouhard, G.J.; Rice, L.M. Microtubule dynamics: An interplay of biochemistry and mechanics. Nat. Rev. Mol. Cell Biol. 2018, 19, 451-463. [CrossRef] [PubMed]

71. Gadoth, A.; Kryzer, T.J.; Fryer, J.; McKeon, A.; Lennon, V.A.; Pittock, S.J. Microtubule-associated protein 1B: Novel paraneoplastic biomarker. Ann. Neurol. 2017, 81, 266-277. [CrossRef]

72. Luo, J.; Hu, Q.; Gou, M.; Liu, X.; Qin, Y.; Zhu, J.; Cai, C.; Tian, T.; Tu, Z.; Du, Y.; et al. Expression of Microtubule-Associated Proteins in Relation to Prognosis and Efficacy of Immunotherapy in Non-Small Cell Lung Cancer. Front. Oncol. 2021, 11, 680402. [CrossRef] [PubMed]

73. Xia, X.; He, C.; Wu, A.; Zhou, J.; Wu, J. Microtubule-Associated Protein 4 Is a Prognostic Factor and Promotes Tumor Progression in Lung Adenocarcinoma. Dis. Markers 2018, 2018, 8956072. [CrossRef] [PubMed]

74. Wolff, S.; Xiao, Z.; Wittau, M.; Süssner, N.; Stöter, M.; Knippschild, U. Interaction of casein kinase 1 delta (CK1 delta) with the light chain LC2 of microtubule associated protein 1A (MAP1A). Biochim. Biophys. Acta 2005, 1745, 196-206. [CrossRef]

75. Kuret, J.; Johnson, G.S.; Cha, D.; Christenson, E.R.; DeMaggio, A.J.; Hoekstra, M.F. Casein kinase 1 is tightly associated with paired-helical filaments isolated from Alzheimer's disease brain. J. Neurochem. 1997, 69, 2506-2515. [CrossRef] [PubMed]

76. Singh, T.J.; Grundke-Iqbal, I.; Iqbal, K. Phosphorylation of tau protein by casein kinase-1 converts it to an abnormal Alzheimer-like state. J. Neurochem. 1995, 64, 1420-1423. [CrossRef]

77. Hanger, D.P.; Byers, H.L.; Wray, S.; Leung, K.-Y.; Saxton, M.J.; Seereeram, A.; Reynolds, C.H.; Ward, M.A.; Anderton, B.H. Novel phosphorylation sites in tau from Alzheimer brain support a role for casein kinase 1 in disease pathogenesis. J. Biol. Chem. 2007, 282, 23645-23654. [CrossRef] [PubMed]

78. Papin, S.; Paganetti, P. Emerging Evidences for an Implication of the Neurodegeneration-Associated Protein TAU in Cancer. Brain Sci. 2020, 10, 862. [CrossRef] [PubMed]

79. Huda, M.N.; Da Kim, H.; Erdene-Ochir, E.; Kim, Y.S.; Pan, C.-H. Expression, phosphorylation, localization, and microtubule binding of tau in colorectal cell lines. Appl. Biol. Chem. 2016, 59, 807-812. [CrossRef]

80. Kit, O.I.; Vodolazhsky, D.I.; Kutilin, D.S.; Enin, Y.S.; Gevorkyan, Y.A.; Zolotukhin, P.V.; Boumber, Y.; Kharin, L.V.; Panina, S.B. A Proteomics Analysis Reveals 9 Up-Regulated Proteins Associated with Altered Cell Signaling in Colon Cancer Patients. Protein J. 2017, 36, 513-522. [CrossRef] [PubMed]

81. Souter, S.; Lee, G. Microtubule-associated protein tau in human prostate cancer cells: Isoforms, phosphorylation, and interactions. J. Cell. Biochem. 2009, 108, 555-564. [CrossRef]

82. Wahl, A.F.; Donaldson, K.L.; Fairchild, C.; Lee, F.Y.; Foster, S.A.; Demers, G.W.; Galloway, D.A. Loss of normal p53 function confers sensitization to Taxol by increasing G2/M arrest and apoptosis. Nat. Med. 1996, 2, 72-79. [CrossRef]

83. Meek, D.W. The role of p53 in the response to mitotic spindle damage. Pathol. Biol. 2000, 48, 246-254. [PubMed]

84. Tarapore, P.; Fukasawa, K. Loss of p53 and centrosome hyperamplification. Oncogene 2002, 21, 6234-6240. [CrossRef] [PubMed]

85. Lopes, C.A.M.; Mesquita, M.; Cunha, A.I.; Cardoso, J.; Carapeta, S.; Laranjeira, C.; Pinto, A.E.; Pereira-Leal, J.B.; Dias-Pereira, A.; Bettencourt-Dias, M.; et al. Centrosome amplification arises before neoplasia and increases upon p53 loss in tumorigenesis. J. Cell Biol. 2018, 217, 2353-2363. [CrossRef] [PubMed]

86. Ho, T.; Tan, B.X.; Lane, D. How the Other Half Lives: What p53 Does When It Is Not Being a Transcription Factor. Int. J. Mol. Sci. 2019, 21, 13. [CrossRef]

87. Song, L.; Dai, T.; Xiong, H.; Lin, C.; Lin, H.; Shi, T.; Li, J. Inhibition of centriole duplication by centrobin depletion leads to p38-p53 mediated cell-cycle arrest. Cell. Signal. 2010, 22, 857-864. [CrossRef]

88. Shinmura, K.; Bennett, R.A.; Tarapore, P.; Fukasawa, K. Direct evidence for the role of centrosomally localized p53 in the regulation of centrosome duplication. Oncogene 2007, 26, 2939-2944. [CrossRef]

89. Tarapore, P.; Horn, H.F.; Tokuyama, Y.; Fukasawa, K. Direct regulation of the centrosome duplication cycle by the p53-p21 Waf1/Cip1 pathway. Oncogene 2001, 20, 3173-3184. [CrossRef]

90. Oikawa, T.; Okuda, M.; Ma, Z.; Goorha, R.; Tsujimoto, H.; Inokuma, H.; Fukasawa, K. Transcriptional control of BubR1 by p53 and suppression of centrosome amplification by BubR1. Mol. Cell. Biol. 2005, 25, 4046-4061. [CrossRef]

91. Ciciarello, M.; Mangiacasale, R.; Casenghi, M.; Zaira Limongi, M.; D’Angelo, M.; Soddu, S.; Lavia, P.; Cundari, E. p53 displacement from centrosomes and p53-mediated G1 arrest following transient inhibition of the mitotic spindle. J. Biol. Chem. 2001, 276, 19205-19213. [CrossRef] 
92. Tarapore, P.; Tokuyama, Y.; Horn, H.F.; Fukasawa, K. Difference in the centrosome duplication regulatory activity among p53 'hot spot' mutants: Potential role of Ser 315 phosphorylation-dependent centrosome binding of p53. Oncogene 2001, 20, 6851-6863. [CrossRef]

93. Liu, Q.; Kaneko, S.; Yang, L.; Feldman, R.I.; Nicosia, S.V.; Chen, J.; Cheng, J.Q. Aurora-A abrogation of p53 DNA binding and transactivation activity by phosphorylation of serine 215. J. Biol. Chem. 2004, 279, 52175-52182. [CrossRef] [PubMed]

94. Tritarelli, A.; Oricchio, E.; Ciciarello, M.; Mangiacasale, R.; Palena, A.; Lavia, P.; Soddu, S.; Cundari, E. p53 localization at centrosomes during mitosis and postmitotic checkpoint are ATM-dependent and require serine 15 phosphorylation. Mol. Biol. Cell 2004, 15, 3751-3757. [CrossRef]

95. Mikule, K.; Delaval, B.; Kaldis, P.; Jurcyzk, A.; Hergert, P.; Doxsey, S. Loss of centrosome integrity induces p38-p53-p21-dependent G1-S arrest. Nat. Cell Biol. 2007, 9, 160-170. [CrossRef] [PubMed]

96. Suhail, T.V.; Singh, P.; Manna, T.K. Suppression of centrosome protein TACC3 induces G1 arrest and cell death through activation of p38-p53-p21 stress signaling pathway. Eur. J. Cell Biol. 2015, 94, 90-100. [CrossRef] [PubMed]

97. Knippschild, U.; Milne, D.M.; Campbell, L.E.; DeMaggio, A.J.; Christenson, E.; Hoekstra, M.F.; Meek, D.W. p53 is phosphorylated in vitro and in vivo by the delta and epsilon isoforms of casein kinase 1 and enhances the level of casein kinase 1 delta in response to topoisomerase-directed drugs. Oncogene 1997, 15, 1727-1736. [CrossRef] [PubMed]

98. Yang, P.; Sale, W.S. Casein kinase I is anchored on axonemal doublet microtubules and regulates flagellar dynein phosphorylation and activity. J. Biol. Chem. 2000, 275, 18905-18912. [CrossRef]

99. Ikeda, K.; Zhapparova, O.; Brodsky, I.; Semenova, I.; Tirnauer, J.S.; Zaliapin, I.; Rodionov, V. CK1 activates minus-end-directed transport of membrane organelles along microtubules. Mol. Biol. Cell 2011, 22, 1321-1329. [CrossRef]

100. Gokhale, A.; Wirschell, M.; Sale, W.S. Regulation of dynein-driven microtubule sliding by the axonemal protein kinase CK1 in Chlamydomonas flagella. J. Cell Biol. 2009, 186, 817-824. [CrossRef]

101. Wacker, S.A.; Alvarado, C.; Von Wichert, G.; Knippschild, U.; Wiedenmann, J.; Clauss, K.; Nienhaus, G.U.; Hameister, H.; Baumann, B.; Borggrefe, T.; et al. RITA, a novel modulator of Notch signalling, acts via nuclear export of RBP-J. EMBO J. 2011, 30, 43-56. [CrossRef]

102. Oswald, F.; Kovall, R.A. CSL-Associated Corepressor and Coactivator Complexes. Adv. Exp. Med. Biol. 2018, 1066, 279-295. [CrossRef] [PubMed]

103. Bray, S.J. Notch signalling in context. Nat. Rev. Mol. Cell Biol. 2016, 17, 722-735. [CrossRef] [PubMed]

104. Aster, J.C.; Pear, W.S.; Blacklow, S.C. The Varied Roles of Notch in Cancer. Annu. Rev. Pathol. 2017, 12, 245-275. [CrossRef] [PubMed]

105. Borggrefe, T.; Oswald, F. The Notch signaling pathway: Transcriptional regulation at Notch target genes. Cell. Mol. Life Sci. 2009, 66, 1631-1646. [CrossRef]

106. Nam, Y.; Sliz, P.; Song, L.; Aster, J.C.; Blacklow, S.C. Structural basis for cooperativity in recruitment of MAML coactivators to Notch transcription complexes. Cell 2006, 124, 973-983. [CrossRef]

107. Tabaja, N.; Yuan, Z.; Oswald, F.; Kovall, R.A. Structure-function analysis of RBP-J-interacting and tubulin-associated (RITA) reveals regions critical for repression of Notch target genes. J. Biol. Chem. 2017, 292, 10549-10563. [CrossRef]

108. Wang, H.; Yang, Z.; Liu, C.; Huang, S.; Wang, H.; Chen, Y.; Chen, G. RBP-J-interacting and tubulin-associated protein induces apoptosis and cell cycle arrest in human hepatocellular carcinoma by activating the p53-Fbxw7 pathway. Biochem. Biophys. Res. Commun. 2014, 454, 71-77. [CrossRef]

109. Wang, H.; Chen, G.; Wang, H.; Liu, C. RITA inhibits growth of human hepatocellular carcinoma through induction of apoptosis. Oncol. Res. 2013, 20, 437-445. [CrossRef]

110. Steinhäuser, K.; Klöble, P.; Kreis, N.-N.; Ritter, A.; Friemel, A.; Roth, S.; Reichel, J.M.; Michaelis, J.; Rieger, M.A.; Louwen, F.; et al. Deficiency of RITA results in multiple mitotic defects by affecting microtubule dynamics. Oncogene $2017,36,2146-2159$. [CrossRef]

111. Kreis, N.-N.; Steinhäuser, K.; Ritter, A.; Klöble, P.; Hoock, S.C.; Roth, S.; Louwen, F.; Oswald, F.; Yuan, J. Potential involvement of RITA in the activation of Aurora A at spindle poles during mitosis. Oncogene 2019, 38, 4199-4214. [CrossRef]

112. Hoock, S.C.; Ritter, A.; Steinhäuser, K.; Roth, S.; Behrends, C.; Oswald, F.; Solbach, C.; Louwen, F.; Kreis, N.-N.; Yuan, J. RITA modulates cell migration and invasion by affecting focal adhesion dynamics. Mol. Oncol. 2019, 13, 2121-2141. [CrossRef] [PubMed]

113. Krismer, K.; Bernwinkler, T.; Ehrenberger, T. Home-Scansite 4. Available online: https://scansite4.mit.edu/\#home (accessed on 25 January 2022).

114. Steinmetz, M.O.; Prota, A.E. Microtubule-Targeting Agents: Strategies to Hijack the Cytoskeleton. Trends Cell Biol. 2018, 28, 776-792. [CrossRef] [PubMed]

115. Čermák, V.; Dostál, V.; Jelínek, M.; Libusová, L.; Kovář, J.; Rösel, D.; Brábek, J. Microtubule-targeting agents and their impact on cancer treatment. Eur. J. Cell Biol. 2020, 99, 151075. [CrossRef]

116. Gallego-Jara, J.; Lozano-Terol, G.; Sola-Martínez, R.A.; Cánovas-Díaz, M.; de Diego Puente, T. A Compressive Review about Taxol®: History and Future Challenges. Molecules 2020, 25, 5986. [CrossRef] [PubMed]

117. Zhang, D.; Kanakkanthara, A. Beyond the Paclitaxel and Vinca Alkaloids: Next Generation of Plant-Derived MicrotubuleTargeting Agents with Potential Anticancer Activity. Cancers 2020, 12, 1721. [CrossRef] [PubMed] 
118. Chaudhuri, A.R.; Seetharamalu, P.; Schwarz, P.M.; Hausheer, F.H.; Ludueña, R.F. The interaction of the B-ring of colchicine with alpha-tubulin: A novel footprinting approach. J. Mol. Biol. 2000, 303, 679-692. [CrossRef] [PubMed]

119. Borys, F.; Joachimiak, E.; Krawczyk, H.; Fabczak, H. Intrinsic and Extrinsic Factors Affecting Microtubule Dynamics in Normal and Cancer Cells. Molecules 2020, 25, 3705. [CrossRef]

120. McLoughlin, E.C.; O’Boyle, N.M. Colchicine-Binding Site Inhibitors from Chemistry to Clinic: A Review. Pharmaceuticals 2020, 13, 8. [CrossRef]

121. Ley, C.D.; Horsman, M.R.; Kristjansen, P.E.G. Early effects of combretastatin-A4 disodium phosphate on tumor perfusion and interstitial fluid pressure. Neoplasia 2007, 9, 108-112. [CrossRef]

122. Torijano-Gutiérrez, S.; Díaz-Oltra, S.; Falomir, E.; Murga, J.; Carda, M.; Marco, J.A. Synthesis of combretastatin A-4 O-alkyl derivatives and evaluation of their cytotoxic, antiangiogenic and antitelomerase activity. Bioorg. Med. Chem. 2013, 21, 7267-7274. [CrossRef]

123. Abma, E.; Daminet, S.; Smets, P.; Ni, Y.; de Rooster, H. Combretastatin A4-phosphate and its potential in veterinary oncology: A review. Vet. Comp. Oncol. 2017, 15, 184-193. [CrossRef]

124. Kim, T.J.; Ravoori, M.; Landen, C.N.; Kamat, A.A.; Han, L.Y.; Lu, C.; Lin, Y.G.; Merritt, W.M.; Jennings, N.; Spannuth, W.A.; et al. Antitumor and antivascular effects of AVE8062 in ovarian carcinoma. Cancer Res. 2007, 67, 9337-9345. [CrossRef]

125. Long, R.; Yang, W.; Huang, G. Preparation and separation of epothilones with anticancer activity. Chem. Biol. Drug Des. 2020, 96, 785-789. [CrossRef] [PubMed]

126. Bollag, D.M.; McQueney, P.A.; Zhu, J.; Hensens, O.; Koupal, L.; Liesch, J.; Goetz, M.; Lazarides, E.; Woods, C.M. Epothilones, a new class of microtubule-stabilizing agents with a taxol-like mechanism of action. Cancer Res. 1995, 55, 2325-2333. [PubMed]

127. Puhalla, S.; Brufsky, A. Ixabepilone: A new chemotherapeutic option for refractory metastatic breast cancer. Biologics 2008, 2 , 505-515. [CrossRef]

128. Kamal, A.; Hussaini, S.M.A.; Nayak, V.L.; Malik, M.S.; Sucharitha, M.L.; Shaik, T.B.; Ashraf, M.; Bagul, C. Synthesis of 2anilinopyridine dimers as microtubule targeting and apoptosis inducing agents. Bioorg. Med. Chem. 2014, 22, 6755-6767. [CrossRef] [PubMed]

129. Kamal, A.; Khan, M.N.A.; Srinivasa Reddy, K.; Rohini, K. Synthesis of a new class of 2-anilino substituted nicotinyl arylsulfonylhydrazides as potential anticancer and antibacterial agents. Bioorg. Med. Chem. 2007, 15, 1004-1013. [CrossRef]

130. Patel, F.; Spassieva, S.D. Side Effects in Cancer Therapy: Are Sphingolipids to Blame? Adv. Cancer Res. 2018, 140, 367-388. [CrossRef]

131. Von Hoff, D.D.; Ervin, T.; Arena, F.P.; Chiorean, E.G.; Infante, J.; Moore, M.; Seay, T.; Tjulandin, S.A.; Ma, W.W.; Saleh, M.N.; et al. Increased survival in pancreatic cancer with nab-paclitaxel plus gemcitabine. N. Engl. J. Med. 2013, 369, 1691-1703. [CrossRef]

132. Nawara, H.M.; Afify, S.M.; Hassan, G.; Zahra, M.H.; Seno, A.; Seno, M. Paclitaxel-Based Chemotherapy Targeting Cancer Stem Cells from Mono- to Combination Therapy. Biomedicines 2021, 9, 500. [CrossRef]

133. Tataroglu Ozyukseler, D.; Basak, M.; Ay, S.; Koseoglu, A.; Arıcı, S.; Oyman, A.; Sürmeli, H.; Turan, M.; Turan, N.; Odabaş, H.; et al. Prognostic factors of ado-trastuzumab emtansine treatment in patients with metastatic HER-2 positive breast cancer. J. Oncol. Pharm. Pract. 2021, 27, 547-554. [CrossRef] [PubMed]

134. Sells, T.B.; Chau, R.; Ecsedy, J.A.; Gershman, R.E.; Hoar, K.; Huck, J.; Janowick, D.A.; Kadambi, V.J.; LeRoy, P.J.; Stirling, M.; et al. MLN8054 and Alisertib (MLN8237): Discovery of Selective Oral Aurora A Inhibitors. ACS Med. Chem. Lett. 2015, 6, 630-634. [CrossRef]

135. Li, J.-P.; Yang, Y.-X.; Liu, Q.-L.; Pan, S.-T.; He, Z.-X.; Zhang, X.; Yang, T.; Chen, X.-W.; Wang, D.; Qiu, J.-X.; et al. The investigational Aurora kinase $A$ inhibitor alisertib (MLN8237) induces cell cycle $\mathrm{G}_{2} / \mathrm{M}$ arrest, apoptosis, and autophagy via p38 MAPK and Akt/mTOR signaling pathways in human breast cancer cells. Drug Des. Devel. Ther. 2015, 9, 1627-1652. [CrossRef] [PubMed]

136. Fu, Y.; Zhang, Y.; Gao, M.; Quan, L.; Gui, R.; Liu, J. Alisertib induces apoptosis and autophagy through targeting the AKT/mTOR/AMPK/p38 pathway in leukemic cells. Mol. Med. Rep. 2016, 14, 394-398. [CrossRef] [PubMed]

137. Ren, B.-J.; Zhou, Z.-W.; Zhu, D.-J.; Ju, Y.-L.; Wu, J.-H.; Ouyang, M.-Z.; Chen, X.-W.; Zhou, S.-F. Alisertib Induces Cell Cycle Arrest, Apoptosis, Autophagy and Suppresses EMT in HT29 and Caco-2 Cells. Int. J. Mol. Sci. 2015, 17, 41. [CrossRef]

138. Otto, T.; Horn, S.; Brockmann, M.; Eilers, U.; Schüttrumpf, L.; Popov, N.; Kenney, A.M.; Schulte, J.H.; Beijersbergen, R.; Christiansen, H.; et al. Stabilization of N-Myc is a critical function of Aurora A in human neuroblastoma. Cancer Cell 2009, 15, 67-78. [CrossRef]

139. Niu, H.; Manfredi, M.; Ecsedy, J.A. Scientific Rationale Supporting the Clinical Development Strategy for the Investigational Aurora A Kinase Inhibitor Alisertib in Cancer. Front. Oncol. 2015, 5, 189. [CrossRef] [PubMed]

140. O'Connor, O.A.; Özcan, M.; Jacobsen, E.D.; Roncero, J.M.; Trotman, J.; Demeter, J.; Masszi, T.; Pereira, J.; Ramchandren, R.; Beaven, A.; et al. Randomized Phase III Study of Alisertib or Investigator's Choice (Selected Single Agent) in Patients With Relapsed or Refractory Peripheral T-Cell Lymphoma. J. Clin. Oncol. 2019, 37, 613-623. [CrossRef]

141. Shah, H.A.; Fischer, J.H.; Venepalli, N.K.; Danciu, O.C.; Christian, S.; Russell, M.J.; Liu, L.C.; Zacny, J.P.; Dudek, A.Z. Phase I Study of Aurora A Kinase Inhibitor Alisertib (MLN8237) in Combination With Selective VEGFR Inhibitor Pazopanib for Therapy of Advanced Solid Tumors. Am. J. Clin. Oncol. 2019, 42, 413-420. [CrossRef] [PubMed]

142. Mortlock, A.A.; Foote, K.M.; Heron, N.M.; Jung, F.H.; Pasquet, G.; Lohmann, J.-J.M.; Warin, N.; Renaud, F.; de Savi, C.; Roberts, N.J.; et al. Discovery, synthesis, and in vivo activity of a new class of pyrazoloquinazolines as selective inhibitors of aurora B kinase. J. Med. Chem. 2007, 50, 2213-2224. [CrossRef] [PubMed] 
143. Wilkinson, R.W.; Odedra, R.; Heaton, S.P.; Wedge, S.R.; Keen, N.J.; Crafter, C.; Foster, J.R.; Brady, M.C.; Bigley, A.; Brown, E.; et al. AZD1152, a selective inhibitor of Aurora B kinase, inhibits human tumor xenograft growth by inducing apoptosis. Clin. Cancer Res. 2007, 13, 3682-3688. [CrossRef] [PubMed]

144. Zekri, A.; Mesbahi, Y.; Ghanizadeh-Vesali, S.; Alimoghaddam, K.; Ghavamzadeh, A.; Ghaffari, S.H. Reactive oxygen species generation and increase in mitochondrial copy number: New insight into the potential mechanism of cytotoxicity induced by aurora kinase inhibitor, AZD1152-HQPA. Anti-Cancer Drugs 2017, 28, 841-851. [CrossRef]

145. Ashton, S.; Song, Y.H.; Nolan, J.; Cadogan, E.; Murray, J.; Odedra, R.; Foster, J.; Hall, P.A.; Low, S.; Taylor, P.; et al. Aurora kinase inhibitor nanoparticles target tumors with favorable therapeutic index in vivo. Sci. Transl. Med. 2016, 8, 325ra17. [CrossRef] [PubMed]

146. Janeček, M.; Rossmann, M.; Sharma, P.; Emery, A.; Huggins, D.J.; Stockwell, S.R.; Stokes, J.E.; Tan, Y.S.; Almeida, E.G.; Hardwick, B.; et al. Allosteric modulation of AURKA kinase activity by a small-molecule inhibitor of its protein-protein interaction with TPX2. Sci. Rep. 2016, 6, 28528. [CrossRef] [PubMed]

147. Ottmann, O.G.; Müller-Tidow, C.; Krämer, A.; Schlenk, R.F.; Lübbert, M.; Bug, G.; Krug, U.; Bochtler, T.; Voss, F.; Taube, T.; et al. Phase I dose-escalation trial investigating volasertib as monotherapy or in combination with cytarabine in patients with relapsed/refractory acute myeloid leukaemia. Br. J. Haematol. 2019, 184, 1018-1021. [CrossRef] [PubMed]

148. Rudolph, D.; Steegmaier, M.; Hoffmann, M.; Grauert, M.; Baum, A.; Quant, J.; Haslinger, C.; Garin-Chesa, P.; Adolf, G.R. BI 6727, a Polo-like kinase inhibitor with improved pharmacokinetic profile and broad antitumor activity. Clin. Cancer Res. 2009, 15, 3094-3102. [CrossRef] [PubMed]

149. Gjertsen, B.T.; Schöffski, P. Discovery and development of the Polo-like kinase inhibitor volasertib in cancer therapy. Leukemia 2015, 29, 11-19. [CrossRef] [PubMed]

150. Li, G.; Yin, H.; Kuret, J. Casein kinase 1 delta phosphorylates tau and disrupts its binding to microtubules. J. Biol. Chem. 2004, 279, 15938-15945. [CrossRef] [PubMed]

151. Li, S.-S.; Dong, Y.-H.; Liu, Z.-P. Recent Advances in the Development of Casein Kinase 1 Inhibitors. Curr. Med. Chem. 2021, 28, 1585-1604. [CrossRef]

152. Ikeda, H.; Taira, N.; Hara, F.; Fujita, T.; Yamamoto, H.; Soh, J.; Toyooka, S.; Nogami, T.; Shien, T.; Doihara, H.; et al. The estrogen receptor influences microtubule-associated protein tau (MAPT) expression and the selective estrogen receptor inhibitor fulvestrant downregulates MAPT and increases the sensitivity to taxane in breast cancer cells. Breast Cancer Res. 2010, 12, R43. [CrossRef] [PubMed]

153. Wagner, P.; Wang, B.; Clark, E.; Lee, H.; Rouzier, R.; Pusztai, L. Microtubule Associated Protein (MAP)-Tau: A novel mediator of paclitaxel sensitivity in vitro and in vivo. Cell Cycle 2005, 4, 1149-1152. [CrossRef] [PubMed]

154. Mashhoon, N.; DeMaggio, A.J.; Tereshko, V.; Bergmeier, S.C.; Egli, M.; Hoekstra, M.F.; Kuret, J. Crystal structure of a conformationselective casein kinase-1 inhibitor. J. Biol. Chem. 2000, 275, 20052-20060. [CrossRef] [PubMed]

155. Toyoshima, M.; Howie, H.L.; Imakura, M.; Walsh, R.M.; Annis, J.E.; Chang, A.N.; Frazier, J.; Chau, B.N.; Loboda, A.; Linsley, P.S.; et al. Functional genomics identifies therapeutic targets for MYC-driven cancer. Proc. Natl. Acad. Sci. USA 2012, 109, 9545-9550. [CrossRef] [PubMed]

156. Cheong, J.K.; Nguyen, T.H.; Wang, H.; Tan, P.; Voorhoeve, P.M.; Lee, S.H.; Virshup, D.M. IC261 induces cell cycle arrest and apoptosis of human cancer cells via CK1 $/ \varepsilon$ and Wnt/ $\beta$-catenin independent inhibition of mitotic spindle formation. Oncogene 2011, 30, 2558-2569. [CrossRef]

157. Yuan, F.; Li, D.; Guo, M.; Fang, T.; Sun, J.; Qi, F.; Rao, Q.; Zhao, Z.; Huang, P.; Yang, B.; et al. IC261 suppresses progression of hepatocellular carcinoma in a casein kinase $1 \delta / \varepsilon$ independent manner. Biochem. Biophys. Res. Commun. 2020, 523, 809-815. [CrossRef]

158. Stöter, M.; Krüger, M.; Banting, G.; Henne-Bruns, D.; Knippschild, U. Microtubules depolymerization caused by the CK1 inhibitor IC261 may be not mediated by CK1 blockage. PLoS ONE 2014, 9, e100090. [CrossRef]

159. Xian, J.; Bu, F.; Wang, Y.; Long, F.; Zhang, Z.; Wu, C.; Tao, Y.; Wang, T.; Wang, G. A Rationale for Drug Design Provided by Co-Crystal Structure of IC261 in Complex with Tubulin. Molecules 2021, 26, 946. [CrossRef]

160. Choy, H. Taxanes in combined modality therapy for solid tumors. Crit. Rev. Oncol. Hematol. 2001, 37, 237-247. [CrossRef]

161. Martino, E.; Casamassima, G.; Castiglione, S.; Cellupica, E.; Pantalone, S.; Papagni, F.; Rui, M.; Siciliano, A.M.; Collina, S. Vinca alkaloids and analogues as anti-cancer agents: Looking back, peering ahead. Bioorg. Med. Chem. Lett. 2018, 28, $2816-2826$. [CrossRef]

162. Gridelli, C.; Rossi, A.; Maione, P.; Rossi, E.; Castaldo, V.; Sacco, P.C.; Colantuoni, G. Vascular disrupting agents: A novel mechanism of action in the battle against non-small cell lung cancer. Oncologist 2009, 14, 612-620. [CrossRef]

163. Siri, M.; Behrouj, H.; Dastghaib, S.; Zamani, M.; Likus, W.; Rezaie, S.; Hudecki, J.; Khazayel, S.; Łos, M.J.; Mokarram, P.; et al. Casein Kinase-1-Alpha Inhibitor (D4476) Sensitizes Microsatellite Instable Colorectal Cancer Cells to 5-Fluorouracil via Authophagy Flux Inhibition. Arch. Immunol. Ther. Exp. 2021, 69, 26. [CrossRef] [PubMed]

164. Walton, K.M.; Fisher, K.; Rubitski, D.; Marconi, M.; Meng, Q.-J.; Sládek, M.; Adams, J.; Bass, M.; Chandrasekaran, R.; Butler, T.; et al. Selective inhibition of casein kinase 1 epsilon minimally alters circadian clock period. J. Pharmacol. Exp. Ther. 2009, 330, 430-439. [CrossRef] [PubMed] 
165. Janovska, P.; Verner, J.; Kohoutek, J.; Bryjova, L.; Gregorova, M.; Dzimkova, M.; Skabrahova, H.; Radaszkiewicz, T.; Ovesna, P.; Vondalova Blanarova, O.; et al. Casein kinase 1 is a therapeutic target in chronic lymphocytic leukemia. Blood 2018, 131, 1206-1218. [CrossRef] [PubMed]

166. Rosenberg, L.H.; Lafitte, M.; Quereda, V.; Grant, W.; Chen, W.; Bibian, M.; Noguchi, Y.; Fallahi, M.; Yang, C.; Chang, J.C.; et al Therapeutic targeting of casein kinase $1 \delta$ in breast cancer. Sci. Transl. Med. 2015, 7, 318ra202. [CrossRef]

167. Su, Z.; Song, J.; Wang, Z.; Zhou, L.; Xia, Y.; Yu, S.; Sun, Q.; Liu, S.-S.; Zhao, L.; Li, S.; et al. Tumor promoter TPA activates Wnt/ $\beta$-catenin signaling in a casein kinase 1-dependent manner. Proc. Natl. Acad. Sci. USA 2018, 115, E7522-E7531. [CrossRef]

168. García-Reyes, B.; Witt, L.; Jansen, B.; Karasu, E.; Gehring, T.; Leban, J.; Henne-Bruns, D.; Pichlo, C.; Brunstein, E.; Baumann, U.; et al. Discovery of Inhibitor of Wnt Production 2 (IWP-2) and Related Compounds As Selective ATP-Competitive Inhibitors of

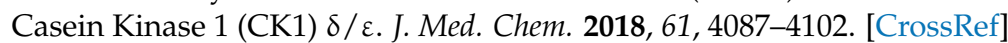

169. Minzel, W.; Venkatachalam, A.; Fink, A.; Hung, E.; Brachya, G.; Burstain, I.; Shaham, M.; Rivlin, A.; Omer, I.; Zinger, A.; et al Small Molecules Co-targeting CKI $\alpha$ and the Transcriptional Kinases CDK7/9 Control AML in Preclinical Models. Cell 2018, 175, 171-185.e25. [CrossRef]

170. Krönke, J.; Fink, E.C.; Hollenbach, P.W.; MacBeth, K.J.; Hurst, S.N.; Udeshi, N.D.; Chamberlain, P.P.; Mani, D.R.; Man, H.W.; Gandhi, A.K.; et al. Lenalidomide induces ubiquitination and degradation of CK1 $\alpha$ in del(5q) MDS. Nature 2015, 523, 183-188. [CrossRef]

171. Deng, C.; Lipstein, M.R.; Scotto, L.; Jirau Serrano, X.O.; Mangone, M.A.; Li, S.; Vendome, J.; Hao, Y.; Xu, X.; Deng, S.-X.; et al Silencing c-Myc translation as a therapeutic strategy through targeting PI3K $\delta$ and $\mathrm{CK} 1 \varepsilon$ in hematological malignancies. Blood 2017, 129, 88-99. [CrossRef]

172. Dhillon, S.; Keam, S.J. Umbralisib: First Approval. Drugs 2021, 81, 857-866. [CrossRef]

173. Anighoro, A.; Bajorath, J.; Rastelli, G. Polypharmacology: Challenges and opportunities in drug discovery. J. Med. Chem. 2014, 57, 7874-7887. [CrossRef]

174. Poornima, P.; Kumar, J.D.; Zhao, Q.; Blunder, M.; Efferth, T. Network pharmacology of cancer: From understanding of complex interactomes to the design of multi-target specific therapeutics from nature. Pharmacol. Res. 2016, 111, 290-302. [CrossRef] [PubMed]

175. Jørgensen, J.T. The importance of predictive biomarkers in oncology drug development. Expert Rev. Mol. Diagn. 2016, 16, 807-809. [CrossRef] [PubMed]

176. Koutsoukas, A.; Simms, B.; Kirchmair, J.; Bond, P.J.; Whitmore, A.V.; Zimmer, S.; Young, M.P.; Jenkins, J.L.; Glick, M.; Glen, R.C.; et al. From in silico target prediction to multi-target drug design: Current databases, methods and applications. J. Proteom. 2011, 74, 2554-2574. [CrossRef] [PubMed]

177. Moffat, J.G.; Rudolph, J.; Bailey, D. Phenotypic screening in cancer drug discovery-past, present and future. Nat. Rev. Drug Discov. 2014, 13, 588-602. [CrossRef] [PubMed]

178. Arnst, K.E.; Banerjee, S.; Chen, H.; Deng, S.; Hwang, D.-J.; Li, W.; Miller, D.D. Current advances of tubulin inhibitors as dual acting small molecules for cancer therapy. Med. Res. Rev. 2019, 39, 1398-1426. [CrossRef] [PubMed]

179. Krüger, M.; Kalbacher, H.; Kastritis, P.L.; Bischof, J.; Barth, H.; Henne-Bruns, D.; Vorgias, C.; Sarno, S.; Pinna, L.A.; Knippschild, U. New potential peptide therapeutics perturbing CK1 / $\alpha$-tubulin interaction. Cancer Lett. 2016, 375, 375-383. [CrossRef]

180. Dolde, C.; Bischof, J.; Grüter, S.; Montada, A.; Halekotte, J.; Peifer, C.; Kalbacher, H.; Baumann, U.; Knippschild, U.; Suter, B. A CK1 FRET biosensor reveals that DDX3X is an essential activator of CK1 1 . J. Cell Sci. 2018, 131, jcs207316. [CrossRef]

181. Cruciat, C.-M.; Dolde, C.; de Groot, R.E.A.; Ohkawara, B.; Reinhard, C.; Korswagen, H.C.; Niehrs, C. RNA helicase DDX3 is a regulatory subunit of casein kinase 1 in Wnt- $\beta$-catenin signaling. Science 2013, 339, 1436-1441. [CrossRef]

182. Harnoš, J.; Ryneš, J.; Víšková, P.; Foldynová-Trantírková, S.; Bajard-Ešner, L.; Trantírek, L.; Bryja, V. Analysis of binding interfaces of the human scaffold protein AXIN1 by peptide microarrays. J. Biol. Chem. 2018, 293, 16337-16347. [CrossRef]

183. Huart, A.-S.; MacLaine, N.J.; Narayan, V.; Hupp, T.R. Exploiting the MDM2-CK1 $\alpha$ protein-protein interface to develop novel biologics that induce UBL-kinase-modification and inhibit cell growth. PLoS ONE 2012, 7, e43391. [CrossRef] [PubMed] 